\title{
High-resolution reconstruction of southwest Atlantic sea-ice and its role in the carbon cycle during marine isotope stages 3 and 2
}

\author{
Lewis G. Collins, ${ }^{1,2}$ Jennifer Pike, ${ }^{3}$ Claire S. Allen, ${ }^{1}$ and Dominic A. Hodgson ${ }^{1}$ \\ Received 9 December 2011; revised 1 June 2012; accepted 4 June 2012; published 22 August 2012.
}

[1] Recent modeling suggests that changes in Southern Ocean sea-ice extent potentially regulated the exchange of $\mathrm{CO}_{2}$ release between the ocean and atmosphere during glacials. Unfortunately, a lack of high-resolution sea-ice records from the Southern Ocean has prevented detailed testing of these model-based hypotheses with field data. Here we present high-resolution records of Southern Ocean sea-ice, for the period 35-15 cal ka BP, derived from diatom assemblages measured in three glacial sediment cores forming an $\sim 8^{\circ}$ transect across the Scotia Sea, southwest Atlantic. Chronological control was achieved through a novel combination of diatom abundance stratigraphy, relative geomagnetic paleointensity data, and down-core magnetic susceptibility and ice core dust correlation. Results showed that the winter sea-ice edge reached its maximum northward extent of $\sim 53^{\circ} \mathrm{S}$, at least $3^{\circ}$ north of its modern limit, between $\sim 25$ and $\sim 23.5$ cal ka BP, predating the Last Glacial Maximum (LGM). Maximum northward expansion of the summer sea-ice edge also pre-dated the LGM, advancing to at least $61^{\circ} \mathrm{S}$, and possibly as far north as $55^{\circ} \mathrm{S}$ between $\sim 31$ and $\sim 23.5 \mathrm{cal} \mathrm{ka} \mathrm{BP}, \mathrm{a} \sim 12^{\circ}$ advance from its modern position. A clear shift in the seasonal sea-ice zone is evident following summer sea-ice edge retreat at $\sim 23.5 \mathrm{cal} \mathrm{ka} \mathrm{BP}$, potentially related to austral insolation forcing. This resulted in an expanded seasonal sea-ice zone between $\sim 22.5 \mathrm{cal}$ ka BP and deglaciation. Our field data confirm that Southern Ocean sea-ice had the physical potential to influence the carbon cycle both as a physical barrier and more importantly through the suppression of vertical mixing and cycling of pre-formed nutrients. Our data indicates that Southern Ocean sea-ice was most effective as a physical barrier between $\sim 31$ and $\sim 23.5 \mathrm{cal} \mathrm{ka} \mathrm{BP}$ and as a mechanism capable of reducing vertical mixing between $\sim 22.5$ cal ka BP and deglaciation. However, poor correlations with atmospheric $\mathrm{CO}_{2}$ variability recorded in ice cores, particularly the lack of a $\mathrm{CO}_{2}$ response during a rapid sea-ice meltback event, recorded at our study sites at the same time as Antarctic Isotopic Maximum 2, suggest that Southern Ocean sea-ice in the Scotia Sea did not play a controlling role in atmospheric $\mathrm{CO}_{2}$ variation during the glacial.

Citation: Collins, L. G., J. Pike, C. S. Allen, and D. A. Hodgson (2012), High-resolution reconstruction of southwest Atlantic sea-ice and its role in the carbon cycle during marine isotope stages 3 and 2, Paleoceanography, 27, PA3217, doi:10.1029/2011PA002264.

\section{Introduction}

[2] Due to its extreme seasonal variability Southern Ocean sea-ice exerts a profound impact on physical and biological processes within the Southern Ocean and plays a critical role

\footnotetext{
${ }^{1}$ British Antarctic Survey, NERC, Cambridge, UK.

${ }^{2}$ LOCEAN/IPSL, CNRS, Université Pierre et Marie Curie, Paris, France.

${ }^{3}$ School of Earth and Ocean Sciences, Cardiff University, Cardiff, UK.

Corresponding author: L. G. Collins, OCEAN/IPSL, CNRS, Université Pierre et Marie Curie, Tour 46/00, 4 Place Jussieu, BP100, Paris FR-75252, France. (1clod@locean-ipsl.upmc.fr)

Published in 2012 by the American Geophysical Union.
}

in the modulation of global climate change. In order to understand the past influence of sea-ice on global climate change there are three key parameters which should be studied. The first is the extent of the multiyear permanent summer sea ice (SSI), second is the extent of the seasonal winter sea ice (WSI), and third, the spatial difference between the two, referred to here as the seasonal sea-ice zone (SIZ) (Figure 1).

[3] Under present-day climate conditions, SSI covers an area of up to $4 \times 10^{6} \mathrm{~km}^{2}$ [Arrigo et al., 1997] and is mainly restricted to the Weddell and Ross Seas. In winter the seasonal freezing of the ocean surface causes WSI to form, which increases the ice cover to $\sim 20 \times 10^{6} \mathrm{~km}^{2}$ [Arrigo et al., 1997]. The seasonal SIZ is important as it determines the spatial area where processes such as deep water formation, deep ocean 


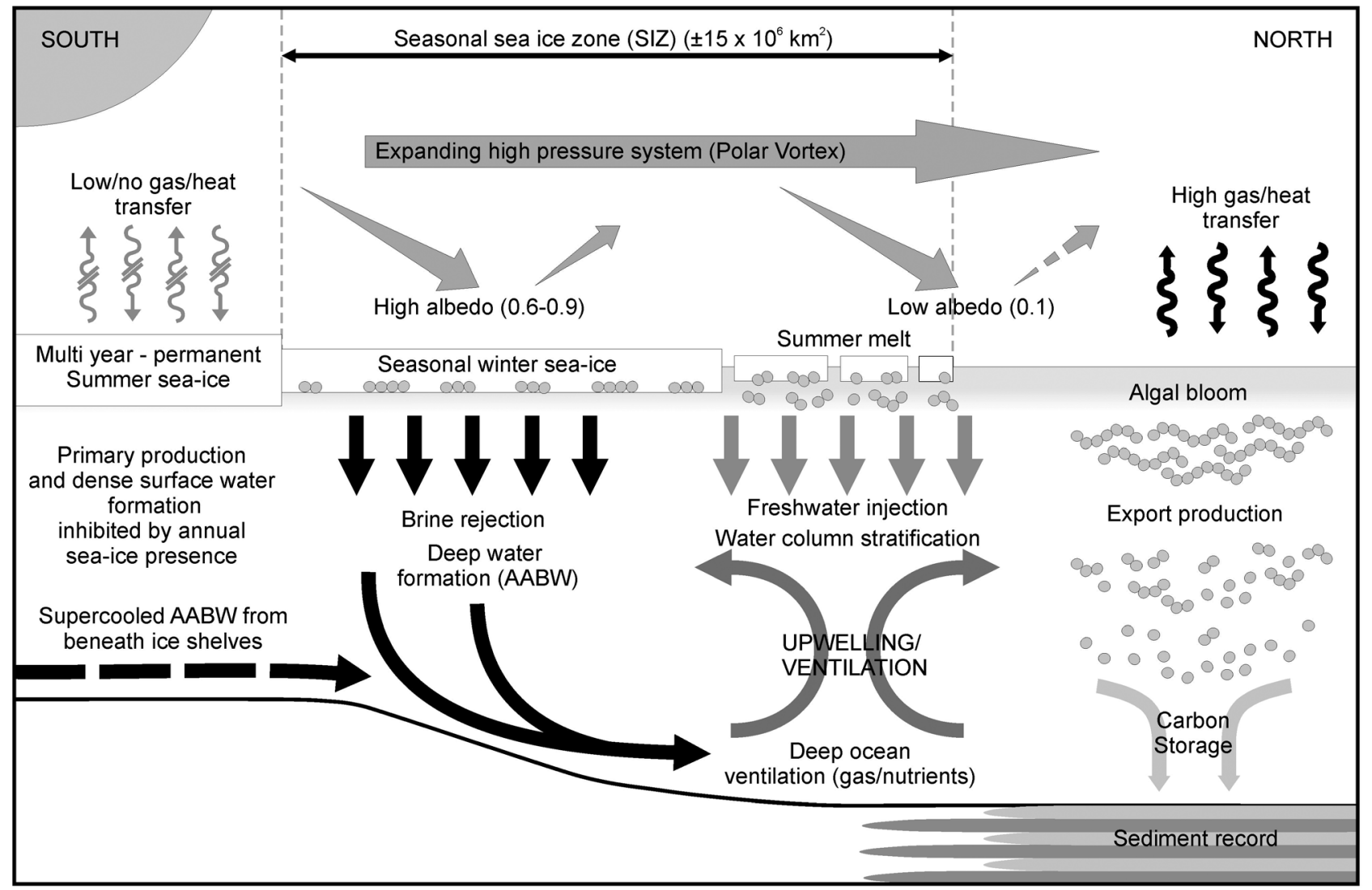

Figure 1. Schematic representation of the primary environmental and climatic influences of sea-ice seasonal change in the Southern Ocean (adapted from Gersonde and Zielinski [2000]).

ventilation, air-sea heat/gas exchange and export production from the surface can occur. All these processes play a critical role in modulating global climate [Ackley, 1980; Bentley, 1984; Foldvik and Gamelsrod, 1988; Gordon, 1991; Wu et al., 1997] (Figure 1). For example, where SSI is present it significantly inhibits the air-sea transfer of heat and gases such as $\mathrm{CO}_{2}$ between the surface ocean and the atmosphere [Bopp et al., 2003] and limits primary production (Figure 1). Alternatively, in the seasonal SIZ heat loss to the atmosphere cools the surface waters and forms WSI. Brine rejection during WSI formation increases the salinity and density of surface waters, which sink and ultimately produce Antarctic bottom water (AABW), the densest water mass in the global ocean, which is critical in maintaining Southern Ocean circulation [Diekmann et al., 2003] (Figure 1). The presence of WSI also provides seasonal limits to air-sea heat and gas exchange, preventing $\mathrm{CO}_{2}$ out-gassing and surface water warming [Takahashi et al., 2009]. Spring and summer melting of WSI in the seasonal SIZ freshens and stratifies surface waters at the retreating WSI edge, suppressing upwelling, generating algal blooms and promoting export production [Holm-Hansen and Mitchell, 1991] (Figure 1). Sea-ice also affects the global energy balance due to its considerably higher albedo than open waters [Brandt et al., 2005] (Figure 1). Collectively, the processes outlined above make Southern Ocean sea-ice an important component in the global climate system, with spatial changes in SSI, WSI and the extent of the seasonal SIZ having the potential to intensify interhemispheric climate changes. As a result, Southern Ocean sea-ice research has grown in prominence over recent years [Gildor and Tziperman, 2001; Knorr and Lohmann, 2003; Shin et al., 2003; EPICA Community Members, 2006], particularly with respect to orbital- and millennial-scale variations in atmospheric $\mathrm{CO}_{2}$ concentrations [Stephens and Keeling, 2000; Liu et al., 2005; Watson and Garabato, 2006; Wolff et al., 2006; Fischer et al., 2010; Sigman et al., 2010]. Understanding the mechanisms responsible for past $\mathrm{CO}_{2}$ fluctuations is one of the most important goals of current climate research. Carbon cycle models have only recently been able to resolve the $\sim 100$ ppmv glacial atmospheric $\mathrm{CO}_{2}$ reduction observed in ice cores [EPICA Community Members, 2006]. These models suggest that changes in Southern Ocean hydrology (which is heavily influenced by sea-ice), affecting circulation and export production of organic matter, are likely the most important factors facilitating these $\mathrm{CO}_{2}$ changes [Fischer et al., 2010]. However, the involvement of sea-ice in complex global climate models is generally limited to the North Atlantic, with considerable uncertainty surrounding Southern Ocean sea-ice dynamics [Clement and Peterson, 2008]. Those models that do include Southern Ocean sea-ice are often less complex boxmodels, which tend to over-simplify the sea-ice environment [Arzel et al., 2006; Randall et al., 2007].

[4] In order to more fully incorporate the Southern Ocean into models that evaluate the role of sea-ice in the carbon cycle and interhemispheric climatic change, detailed reconstructions of glacial sea-ice evolution in key areas of the Southern Ocean are required. Existing reconstructions have 


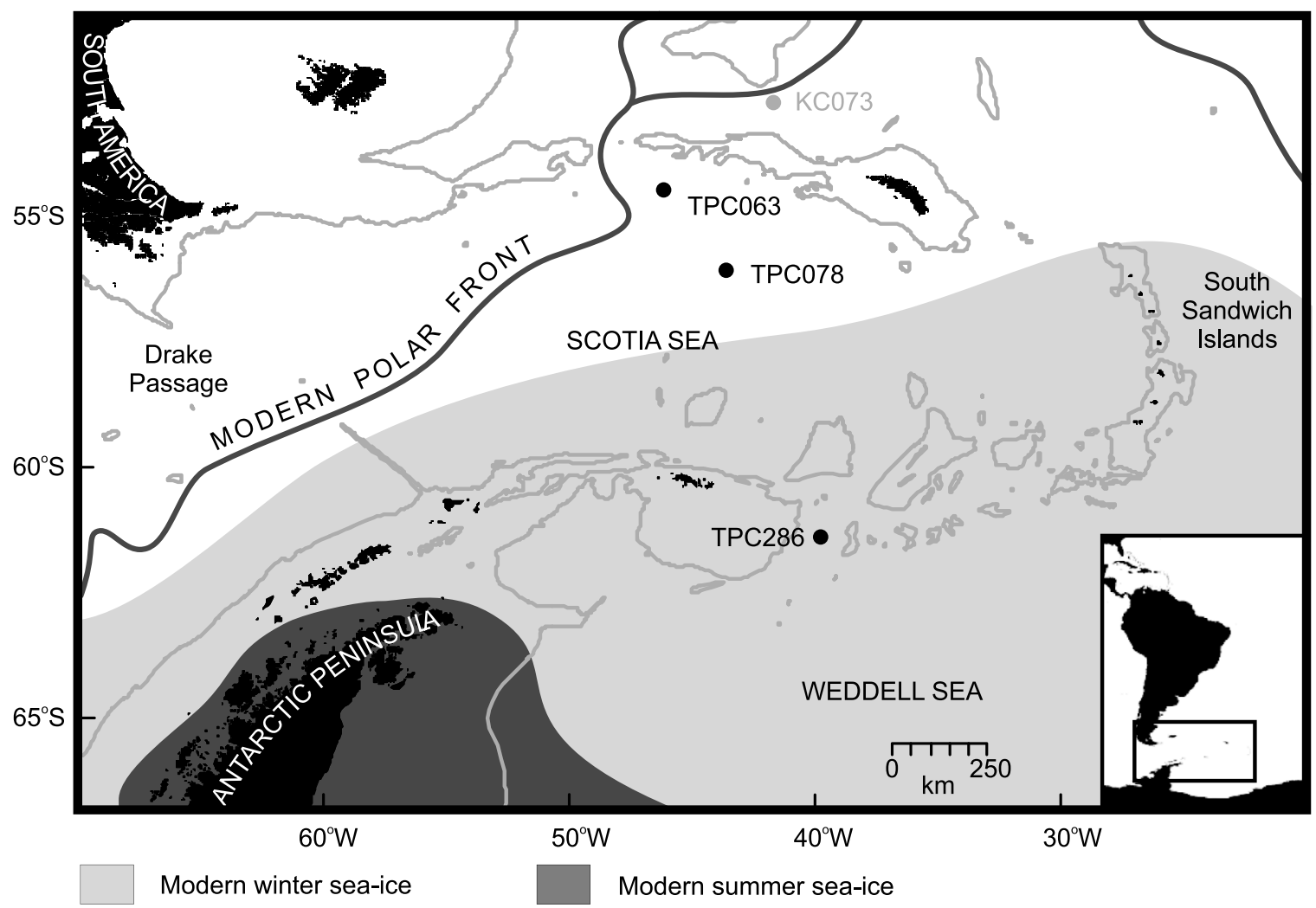

Figure 2. Map of the Scotia Sea, Weddell Sea, Scotia Arc, Antarctic Polar Front, seasonal sea-ice limits and the locations of the sediment cores analyzed in this study and core KC073 analyzed in Allen et al. [2005]. The $2000 \mathrm{~m}$ depth contour is also shown to provide an impression of the main bathymetric features of the region (based on British Antarctic Survey [2007]).

focused on LGM time-slices and the Holocene, with little attention paid to MIS 3, MIS 2 and the last deglaciation [Crosta et al., 1998a, 1998b; Gersonde and Zielinski, 2000; Shemesh et al., 2002; Gersonde et al., 2003, 2005] and those studies that do span these periods are inconsistent with each other in their interpretations of the extent of the Antarctic seasonal SIZ. Early studies, using lithological boundaries and sediment facies of the seafloor as indicators of past seaice extent, propose a much reduced glacial seasonal SIZ in comparison to the present [Hays et al., 1976; Cooke and Hays, 1982; CLIMAP Project Members, 1976, 1981]. CLIMAP Project Members [1976, 1981] place the maximum glacial SSI edge at the modern WSI edge and the maximum glacial WSI edge halfway between the modern WSI edge and the modern Antarctic Polar Front (APF). More recently, studies using sea-ice related subfossil diatoms preserved within sediment records have re-assessed the CLIMAP results and proposed an expansive seasonal SIZ at the LGM $\left(\sim 18{ }^{14} \mathrm{C}\right.$ ka) placing the maximum WSI edge at the modern position of the APF and SSI edge not far from its modern limit [Crosta et al. 1998a, 1998b]. Gersonde et al. [2005] support this proposed position of the maximum WSI edge [Crosta et al. 1998a, 1998b], but suggest a maximum LGM SSI edge near the margins of the modern WSI edge. This large change in the extent of SSI would reduce the extent of the seasonal SIZ proposed by Crosta et al. [1998a], but would still result in a seasonal SIZ greater than present at the LGM. More recently Allen et al. [2011] have proposed that
WSI extent was at least $5^{\circ}$ further north at the LGM and expanded from approximately $61^{\circ} \mathrm{S}$ to $52^{\circ} \mathrm{S}$ each season. Allen et al. [2011] also found evidence of SSI extending to $59^{\circ} \mathrm{S}$ during the last glacial, close to the modern mean WSI limit and most importantly, despite limited chronological control, this maximum sea ice extent pre-dated the LGM.

[5] Given the potential significance of the Allen et al. [2011] proposal of a pre-LGM maximum SSI extent, we re-sampled the sediments from two existing (TPC063 and TPC078) and one new (TPC286) sediment core in a transect across the Scotia Sea. Our aims were to: (1) improve chronological control on the sediment records during MIS 3 and MIS 2; (2) reconstruct sea-ice changes at higher resolution using diagnostic diatom assemblages; (3) test the Allen et al. [2011] hypothesis that the maximum mean SSI limit predated the LGM; (4) compare our diatom-based reconstruction with ice core ssNa ${ }^{+}$-derived sea-ice reconstructions and (5) using our new data, assess the extent to which sea-iceassociated mechanisms may have modulated atmospheric $\mathrm{CO}_{2}$ between 35 and 15 cal ka BP.

\section{Materials and Methods}

\subsection{Study Area}

[6] The Scotia Sea is located in the South Atlantic sector of the Southern Ocean, north of the Weddell Sea (Figure 2). The modern mean WSI edge cuts across the basin, between the southern margin of Drake Passage and north of the South 
Table 1. Core Data for TPC286, TPC078 and TPC063 ${ }^{\mathrm{a}}$

\begin{tabular}{ccccccc}
\hline Core Name & Latitude $(\mathrm{S})$ & Longitude $(\mathrm{N})$ & Length $(\mathrm{m})$ & Water Depth $(\mathrm{m})$ & Cruise & Research Vessel \\
\hline TPC286 & $61^{\circ} 47^{\prime} 24^{\prime \prime}$ & $40^{\circ} 8^{\prime} 24^{\prime \prime}$ & 9.35 & 3467 & JR48 (2002) & RRS James Clark Ross \\
TPC078 & $55^{\circ} 32^{\prime} 60^{\prime \prime}$ & $45^{\circ} 1^{\prime} 12^{\prime \prime}$ & 4.2 & 3840 & JR04 (1993) & RRS James Clark Ross \\
TPC063 & $53^{\circ} 55^{\prime} 48^{\prime \prime}$ & $48^{\circ} 2^{\prime} 24^{\prime \prime}$ & 7.07 & 3956 & JR04 (1993) & RRS James Clark Ross \\
\hline
\end{tabular}

${ }^{\mathrm{a}} \mathrm{TPC}$ refers to the trigger core (TC) and piston core (PC) composite, spliced using magnetic susceptibility and lithology records.

Sandwich Islands. The modern mean SSI edge skirts the western edge of the Antarctic Peninsula and turns south and east, into and across the Weddell Sea (Figure 2). The bathymetry of the Scotia Sea includes a series of discontinuous ridges that provide some sheltered sedimentary environments, allowing the formation of sediment drift deposits protected from the scouring effects of the Antarctic Circumpolar Current (ACC), which flows across the Scotia Sea from Drake Passage. Sedimentation within the Scotia Sea is therefore primarily controlled by ocean circulation and seaice distribution [Pudsey and Howe, 1998; Diekmann et al., 2000; Pugh et al., 2009], with sedimentary proxies in the drift deposits recording variations in these parameters through time. The study sites were located to reconstruct changes in the extent and duration of sea-ice in this sector during the last glacial period.

\subsection{Cores}

[7] Two of the three sediment cores analyzed in this study,

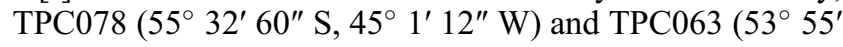
$48^{\prime \prime} \mathrm{S}, 48^{\circ} 2^{\prime} 24^{\prime \prime} \mathrm{W}$ ), were selected on the basis of the previous lower resolution study [Allen et al., 2011], which contained pre-LGM sediments and showed the potential for improved chronologies and relatively high glacial sedimentation rates permitting higher resolution sea-ice reconstructions. The third core, TPC286 (61 $\left.47^{\circ} 24^{\prime \prime} \mathrm{S}, 40^{\circ} 8^{\prime} 24^{\prime \prime} \mathrm{W}\right)$, was recovered from a more southerly drift deposit sharing similar sedimentary characteristics, to better assess the history of summer sea-ice migrations (Figure 2 and Table 1). The cores form an $\sim 8^{\circ}$ transect across the Scotia Sea. Core TPC286, located on the southern flank of the South Scotia Ridge, is currently exposed to the seasonal encroachment of WSI, with the WSI edge lying $\sim 550 \mathrm{~km}$ to the north and the SSI edge to the south. Core TPC063 is located just south of the North Scotia Ridge and Shag Rocks Passage, lies approximately $450 \mathrm{~km}$ north of the modern WSI edge and close to the glacial WSI edge proposed by Gersonde et al. [2005]. Core TPC078, located in the northern Central Scotia Sea, between core sites TPC286 and TPC063, also lies to the north of the modern WSI edge, by c. $200 \mathrm{~km}$.

\subsection{Age Control}

[8] Conventional dating methods cannot be reliably applied south of the APF. The chronologies for cores TPC286 and TPC063 were therefore based primarily on the correlation of down-core records of relative paleointensity (RPI) with an independently dated RPI stack, and the identification of biostratigraphic datums. Cores TPC286 and TPC063 were initially correlated using Automatic Correlation Software (ACS) [Hofmann et al., 2005]. Based on 13 pairs of stratigraphic tiepoints, identified in a number of magnetic and biostratigraphic proxies, TPC063 depths were converted to TPC286 depth equivalents $\left(\mathrm{r}^{2}=0.999\right)$ (Figure 3) [Collins et al., 2012]. A combined (TPC063 + TPC286) RPI stack was generated and correlated with the SAPIS RPI stack from the South Atlantic [Stoner et al., 2002], independently dated via 14 radiocarbon dates [Charles et al., 1996], with an associated calendar age error of $\sim 500$ years between 15 and $25 \mathrm{cal} \mathrm{ka} \mathrm{BP,} \mathrm{increasing}$ to $\sim 1500$ year at $41 \mathrm{cal} \mathrm{ka} \mathrm{BP} \mathrm{[Charles} \mathrm{et} \mathrm{al.,} \mathrm{1996]} \mathrm{(Figure} \mathrm{4).}$ The two RPI stacks were correlated based on comparable highs and lows in RPI at 5 points in the respective records, which included the accurately dated Laschamp geomagnetic excursion [Guillou et al., 2004] (Figure 4), independently identified in TPC063, TPC286 [Collins et al., 2012] and the SAPIS stack [Stoner et al., 2002]. Identification of the Eucampia antarctica deglaciation datum [Burckle and Cooke, 1983], estimated at $17.3( \pm 0.5)$ cal ka BP [Schaefer et al., 2006], provided an additional chronological constraint (Figure 4). Linear rates of sedimentation were assumed between all chronological tie-points and between the deglaciation datum and the core top. The resulting chronologies for cores TPC286 and TPC063 provide mean sedimentation rates of $\sim 9$ and $\sim 14 \mathrm{~cm} / \mathrm{kyr}, \sim 34$ and $\sim 42 \mathrm{~cm} / \mathrm{kyr}$, and $\sim 3$ and $\sim 5 \mathrm{~cm} / \mathrm{kyr}$ for the periods $35-25 \mathrm{cal} \mathrm{ka} \mathrm{BP,} \mathrm{25-17.3}$ cal ka BP and 17.3-15 cal ka BP, respectively (Figure 4). Based on a sampling resolution of $0.04 \mathrm{~m}$ these rates of sedimentation equate to a temporal resolution of 0.4 and $0.3 \mathrm{kyr}$, $0.1 \mathrm{kyr}$, and 1.4 and $0.7 \mathrm{kyr}$ for each respective core and time period.

[9] The chronology for core TPC078 follows Pugh et al. [2009] and is based on correlations between down-core

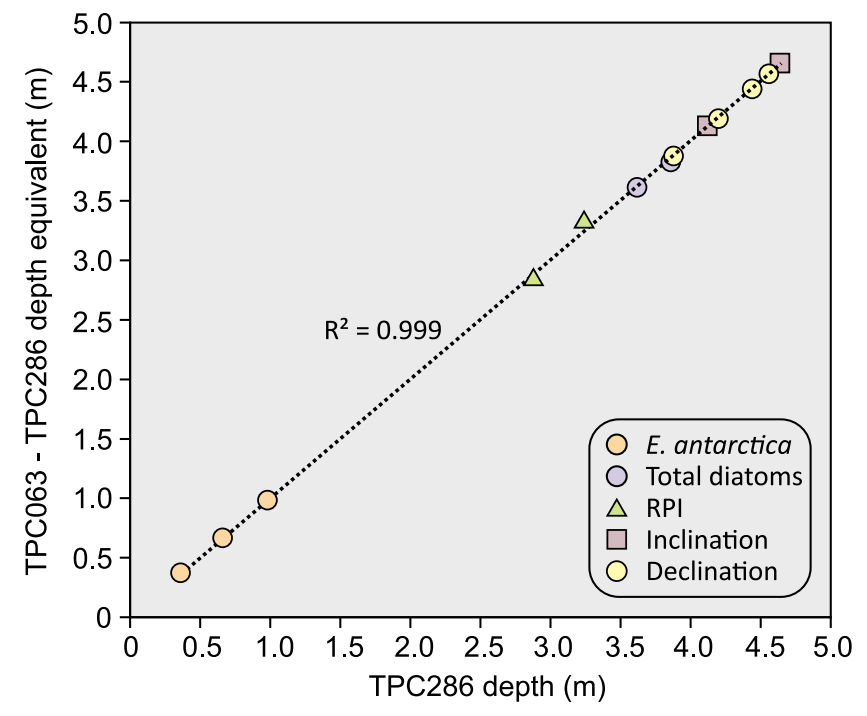

Figure 3. Comparison of TPC 286 depth model with the TPC063-TPC286 depth-equivalent model post core correlation. Tie-points taken from Eucampia antarctica relative abundance (orange circles), total diatom abundance (blue circles), relative paleointensity (green triangles), inclination (mauve squares) and declination (yellow circles). 

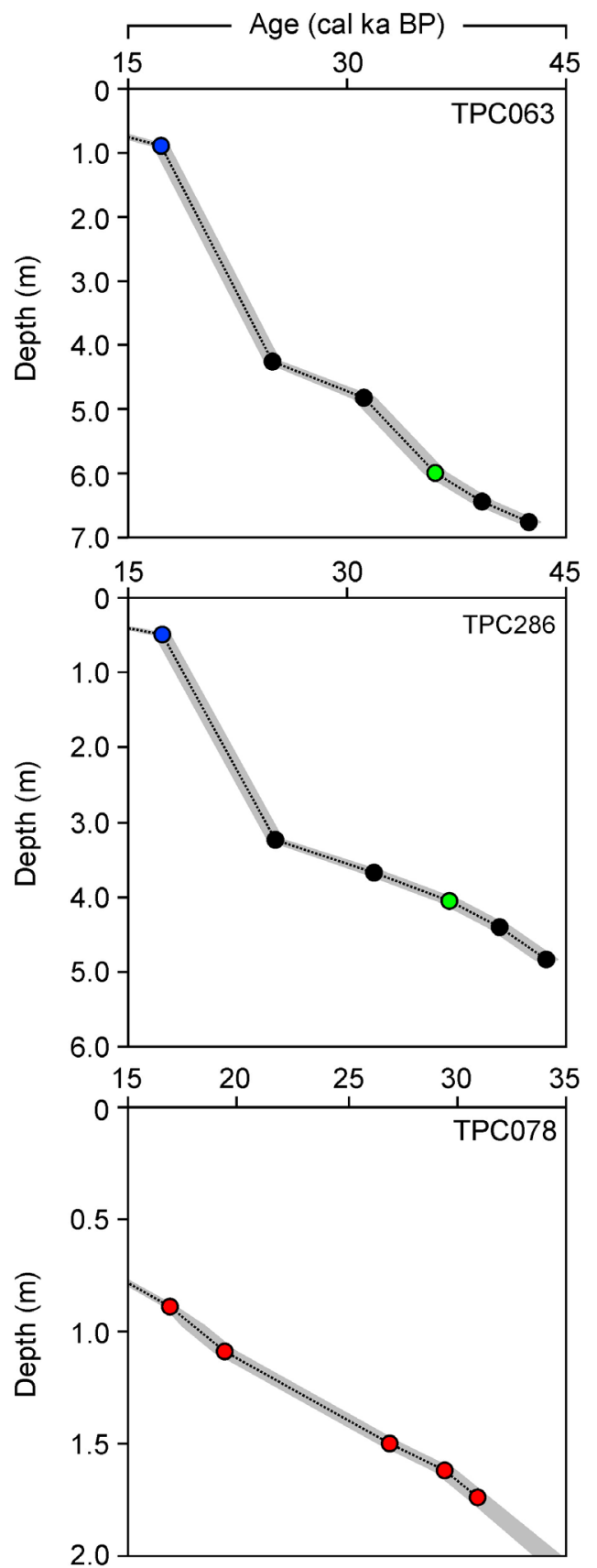

- E. antarctic deglaciation datum

- RPI correlation tie-points (SAPIS)

- Laschamp excursion

- MS/dust correlation tie-points (EDC3)

Field of potential error

Figure 4. Summary of sediment core chronologies for TPC063, TPC286 and TPC078. Chronologies and biostratigraphic (blue circles), paleomagnetic (black and green circles, Laschamp excursion) and magnetic susceptibility/dust (orange circles) age-depth tie points are fully described in Pugh et al. [2009] and Collins et al. [2012]. volume-specific magnetic susceptibility of the bulk sediment, and EPICA Dome C (EDC) dust records, essentially applying the EDC3 ice core age-model [Parrenin et al., 2007] to core TPC078. The correlation was validated through ${ }^{14} \mathrm{C}$ dating of the acid insoluble organic fraction back to $30 \mathrm{ka}$. The correlation of EDC dust concentration on the EDC3 time-scale, with down-core magnetic susceptibility was carried out using the time series program Analyseries [Paillard et al., 1996]. Maxima, minima and transitions between maxima and minima in the two records were used to identify five tie-points between 35 and $17 \mathrm{cal} \mathrm{ka}$ BP (Figure 4). With respect to the time period investigated in this study errors in the EDC 3 chronology increase from 400 years at $14 \mathrm{ka}$, to $1 \mathrm{kyr}$ at $18 \mathrm{ka}$, and to $1.5 \mathrm{kyr}$ at $40 \mathrm{ka}$ [Parrenin et al., 2007] (Figure 4). The resulting age model provides mean sedimentation rates of between 5 and $8 \mathrm{~cm} /$ kyr for the period 31-15 cal ka BP (Figure 4) which, at a sampling resolution of $0.08 \mathrm{~m}$, equates to a temporal resolution of $\sim 1.5 \mathrm{kyr}$. Linear rates of sedimentation were assumed between all tie-points, and between $17.3 \mathrm{cal}$ ka BP and the core top.

[10] The novel combination of these techniques improves chronological control on our sediment records of the Scotia Sea during MIS 3 and MIS 2; however, we acknowledge the potential for further errors resulting from tie-point interpolation when comparing these chronologies with each other and other paleoclimate records.

\subsection{Diatom Analysis}

[11] Reconstructions of past sea ice extent are based on changes in sedimentary marine diatom assemblages [Leventer et al., 1996; Crosta et al., 1998a; Cunningham et al., 1999; Taylor et al., 2001; Taylor and Leventer, 2003] which are typically well-preserved in Southern Ocean sediments [Leventer and Dunbar, 1996; Cunningham and Leventer, 1998; Armand et al., 2005; Crosta et al., 2005b]. Based on sediment traps, surface sediments and Late Pleistocene sediment cores Gersonde and Zielinski [2000] showed that fossil sea-ice diatoms can be used as a robust proxy to estimate past seasonal sea-ice extent. Relative combined abundances of the sea-ice diatom species Fragilariopsis curta (Van Heurck) Hustedt and Fragilariopsis cylindrus (Grunow) Krieger of $>3 \%$ have been proposed as an indicator of the seasonal WSI edge whereas relative abundances of the sea-ice diatom Fragilariopsis obliquecostata (Van Heurck) Heiden in Heiden et Kolbe of $>3 \%$, combined with low rates of biogenic sedimentation (surface water primary production is inhibited by annual sea-ice cover), have been proposed as an indicator of the repeated presence of the SSI edge and perennial sea-ice cover. This calibration by Gersonde and Zielinski [2000] has been widely applied to Southern Ocean sediments and is presently the most widely used tool for Southern Ocean seaice reconstruction. Cores TPC286 and TPC063 were sampled at a resolution of $0.04-0.16 \mathrm{~m}$ and core TPC078 was sampled at a resolution of $0.08 \mathrm{~m}$. Sample preparation followed Scherer [1994] enabling diatom concentrations to be calculated, taxonomy followed Tomas [1997], Fryxell and Prasad [1990] and Fryxell and Hasle [1979], and diatom valve counting was carried out using an Olympus BH-2 microscope at 1000x magnification. Diatom assemblage data were based on counts of 300-450 valves per sample or a minimum of 10 slide transects where extremely low absolute diatom abundance 

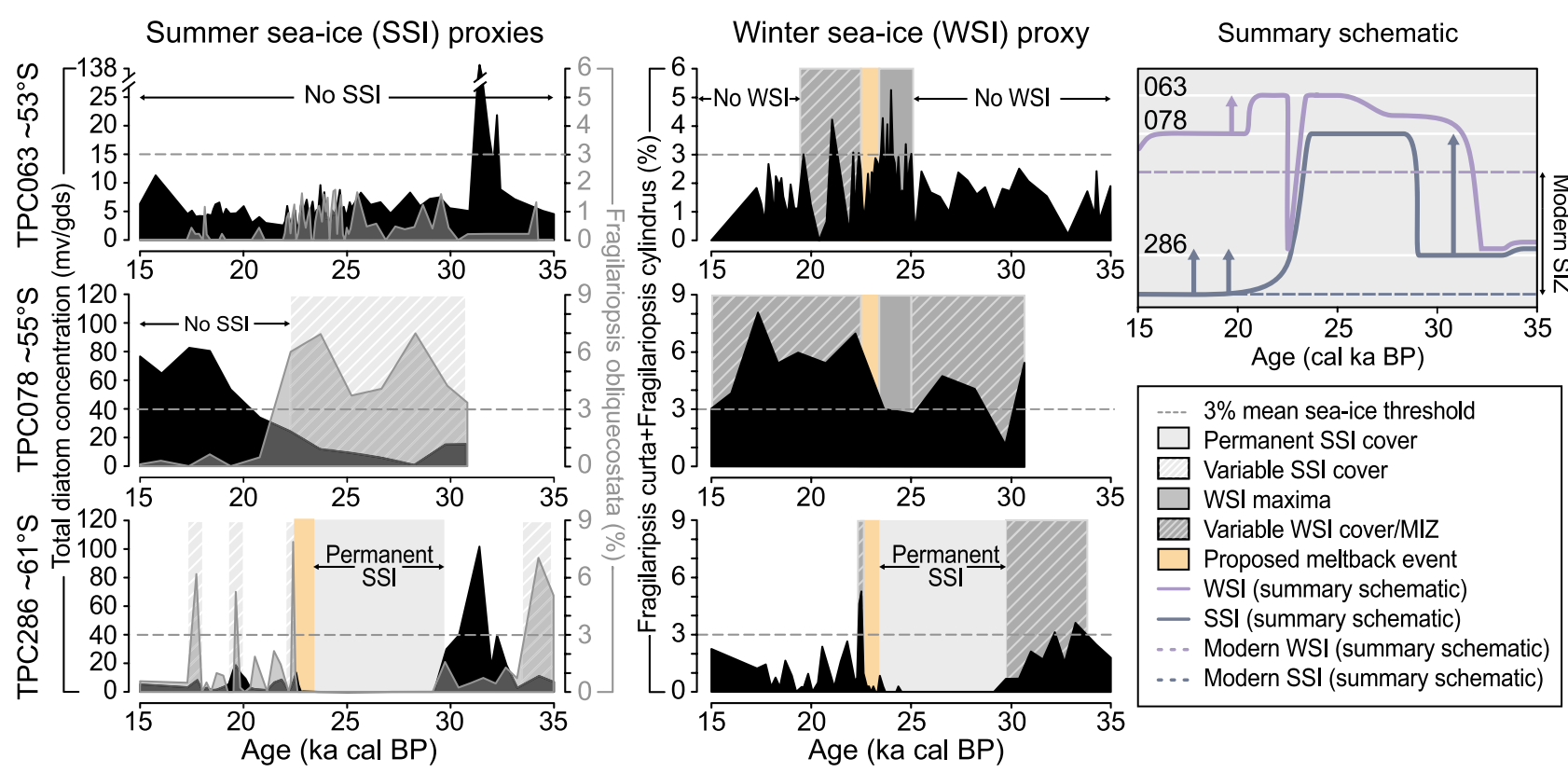

Figure 5. Diatom analyses of cores TPC063, TPC078 and TPC286. The first column shows summer seaice (SSI) proxies in the form of total diatom concentrations and the $\%$ relative abundance of Fragilariopsis obliquecostata. The second column shows the combined \% relative abundance of Fragilariopsis curta and Fragilariopsis cylindrus, a proxy for winter sea ice (WSI). Shaded zones represent our interpretation of these results in terms of sea ice regimes. Horizontal dashed lines indicate the $3 \%$ threshold indicative of the mean position of the sea-ice edge [Gersonde and Zielinski, 2000]. The summary schematic conceptualizes seasonal SIZ dynamics in the Scotia Sea between 35 and 15 cal ka BP, based on these diatom data. Additional acronyms: MIZ, marginal ice zone; SIZ, seasonal sea-ice zone.

precluded assemblage counts [Buffen et al., 2007; Fortin and Dale, 2008].

\section{Results}

\subsection{TPC286}

[12] TPC286 was dominated by glacial sediments, primarily composed of muddy diatom ooze and diatom-bearing clays and muds. Enhanced terrigenous material relative to biogenic material, and the occasional total absence of the latter, reflects a glacial regime characterized by an increased input of glaciogenic detritus and a decrease in surface water productivity [Diekmann et al., 2000]. Low diatom concentrations characterized the base of the record $\left(\sim 5 \times 10^{6}\right.$ valves per grams of dry sediment (v/gds)) between $\sim 35-33$ cal ka BP, prior to a sharp, stepped increase to a large peak $\left(100 \times 10^{6} \mathrm{v} / \mathrm{gds}\right)$ at $\sim 31 \mathrm{cal} \mathrm{ka} \mathrm{BP}$. Concentrations then fell sharply to extremely low values $\left(0.02 \times 10^{6} \mathrm{v} / \mathrm{gds}\right)$ at $\sim 29$ cal ka BP, which persisted until $\sim 23$ cal ka BP, with a mean of just $0.04 \times 10^{6} \mathrm{v} / \mathrm{gds}\left(\sigma=0.01 \times 10^{6}, \mathrm{n}=29\right)$. Concentrations increased to $\sim 14 \times 10^{6} \mathrm{v} / \mathrm{gds}$ at $\sim 22.5 \mathrm{cal} \mathrm{ka}$ $\mathrm{BP}$, and although peaks are present at $21.5\left(6 \times 10^{6} \mathrm{v} / \mathrm{gds}\right)$, $19.5\left(15 \times 10^{6} \mathrm{v} / \mathrm{gds}\right)$ and $\sim 17.8 \mathrm{cal} \mathrm{ka} B P\left(8 \times 10^{6} \mathrm{v} / \mathrm{gds}\right)$, concentrations remained relatively low for the remainder of the record (Figure 5). The relative abundance of $F$. curta + F. cylindrus in core TPC286 increased from $\sim 2 \%$ at $\sim 35$ cal ka BP to a peak of $>3 \%$ at $\sim 33.2$ cal ka BP and then steadily fell to zero at $\sim 29.2 \mathrm{cal} \mathrm{ka} B P$. It remained at zero until $\sim 24$ cal ka BP when relative abundance increased slightly to $<1 \%$. At $\sim 22.5$ cal ka BP, relative abundance peaked at
$4.7 \%$, then decreased to $<3 \%$ relative abundance at $\sim 15 \mathrm{cal} \mathrm{ka}$ BP (Figure 5). The relative abundance of $F$. obliquecostata was approximately $5 \%$ at $\sim 35 \mathrm{cal} \mathrm{ka} \mathrm{BP}$, rising to a peak of $>6 \%$ at $\sim 34.3$ cal ka BP. Relative abundance then fell sharply to $\sim 1 \%$ at $\sim 33.2 \mathrm{cal} \mathrm{ka} \mathrm{BP}$ and remained low until $\sim 29.2 \mathrm{cal}$ ka BP where it fell to zero. F. obliquecostata relative abundance remained at zero until $\sim 22.7 \mathrm{cal} \mathrm{ka}$ BP before it peaked at $\sim 7 \%$ at $\sim 22.4 \mathrm{cal} \mathrm{ka}$ BP. Other than two additional, less prominent peaks at $\sim 19.6 \mathrm{cal} \mathrm{ka} \mathrm{BP}(4.7 \%)$ and $\sim 17.8 \mathrm{cal} \mathrm{ka}$ BP $(5.5 \%)$, relative abundance remained $<2 \%$ until $\sim 15$ cal ka BP (Figure 5).

\subsection{TPC078}

[13] TPC078 sediments were characterized by alternating biogenic and terrigenous units, composed of homogenous diatomaceous mud, diatom ooze and diatom-bearing mud. A sustained period of low diatom concentrations characterized the base of the record, decreasing from $14.8 \times 10^{6} \mathrm{v} / \mathrm{gds}$ at $\sim 31 \mathrm{cal} \mathrm{ka} \mathrm{BP}$ to $0.86 \times 10^{6} \mathrm{v} / \mathrm{gds}$ at $\sim 28.3 \mathrm{cal} \mathrm{ka} \mathrm{BP}$, the lowest concentration in the record. Concentrations increased gradually to $11.9 \times 10^{6} \mathrm{v} / \mathrm{gds}$ by $\sim 22.2 \mathrm{cal}$ ka BP prior to increasing more rapidly to a much higher concentration of $80 \times 10^{6} \mathrm{v} / \mathrm{gds}$ at $\sim 17.4 \mathrm{cal} \mathrm{ka}$ BP. These comparatively high concentrations were maintained to the top of the studied interval ( $\sim 14.5$ cal ka BP) (Figure 5). Relative abundance of $F$. curta $+F$. cylindrus in TPC078 declined from $>5 \%$ to $\sim 1 \%$ between $\sim 31$ and $\sim 29.8$ cal $\mathrm{ka} \mathrm{BP}$, then returned to $\sim 5 \%$ at $\sim 26.6 \mathrm{cal} \mathrm{ka} \mathrm{BP}$. A second decline to $<3 \%$ occurred between $\sim 26.6$ and $\sim 23.7$ cal ka BP. Relative abundance then increased to $\sim 7 \%$ at $\sim 22.2 \mathrm{cal} \mathrm{ka} \mathrm{BP}$ and to 
$\sim 8 \%$ at $\sim 17.4$ cal ka BP. Between $\sim 17.4$ and $\sim 15$ cal ka BP $F$. curta $+F$. cylindrus relative abundance fell to $<3 \%$ (Figure 5). The relative abundance of $F$. obliquecostata increased from $\sim 3 \%$ at $\sim 31 \mathrm{cal} \mathrm{ka} \mathrm{BP}$ to $\sim 7 \%$ at $\sim 28.3 \mathrm{cal} \mathrm{ka}$ BP then fell to $\sim 4 \%$ between $\sim 26.6$ and $\sim 25.2 \mathrm{cal}$ ka BP. Relative abundance increased again to $\sim 7 \%$ at $\sim 23.7 \mathrm{cal} \mathrm{ka}$ $\mathrm{BP}$ and remained above $6 \%$ until $\sim 22.2 \mathrm{cal} \mathrm{ka}$ BP before a rapid decrease to $<1 \%$ by $\sim 20.8 \mathrm{cal} \mathrm{ka} \mathrm{BP}$. Between $\sim 20.8$ and $\sim 15$ cal ka BP relative abundance remained $<1 \%$ (Figure 5).

\subsection{TPC063}

[14] TPC063 was dominated by glacial sediments, primarily characterized by fine diatom-bearing slit clay/mud, which terminated in a stiff layer of bentonite clay. Above this layer of bentonite clay organic-rich Holocene sediment characterized the core. Total diatom concentrations were $\sim 5 \times 10^{6} \mathrm{v} / \mathrm{gds}$ at the base of the record $(\sim 35 \mathrm{cal} \mathrm{ka} \mathrm{BP})$ and increased, gradually then rapidly to an exceptionally large peak $\left(\sim 140 \times 10^{6} \mathrm{v} / \mathrm{gds}\right) \sim 31$ cal ka BP. Concentrations almost immediately returned to low values of between 1.5 and $10 \times 10^{6} \mathrm{v} /$ gds until $\sim 16$ cal ka BP, where a slightly higher peak $\left(\sim 11 \times 10^{6} \mathrm{v} / \mathrm{gds}\right)$ was observed (Figure 5). The relative abundance of $F$. curta $+F$. cylindrus in TPC063 was $\sim 1.7 \%$ at $\sim 35$ cal ka BP and remained below 3\% until $\sim 25.2$ cal ka BP, varying between lows of $\sim 0.2 \%$ and highs of $\sim 2.4 \%$. Between $\sim 25$ and $\sim 23$ cal ka BP, relative abundance exceeded $3 \%$ on several occasions, with highs of $5.3 \%, 4 \%$ and $4.3 \%$ at $\sim 24, \sim 23.8$ and $\sim 23.6$ cal ka BP, respectively. A decline to $<1 \%$ was observed at $\sim 23$ cal ka $\mathrm{BP}$, followed by a period of high amplitude oscillations (between $>3 \%$ and $<1 \%$ ) from $\sim 23$ and $\sim 19.7$ cal ka BP. Relative abundance of $F$. curta $+F$. cylindrus were $<3 \%$ for the remainder of the record, decreasing to $<1 \%$ at $\sim 15 \mathrm{cal} \mathrm{ka}$ BP (Figure 5). The relative abundance of $F$. obliquecostata was $<2 \%$ throughout the record exceeding $1 \%$ on only four occasions between $\sim 35$ and $\sim 25 \mathrm{ka}(\sim 32.4, \sim 30, \sim 29$ and $\sim 25.7$ cal ka BP), more frequently during the period $\sim 25$ $22.2 \mathrm{cal} \mathrm{ka} \mathrm{BP}$, and then once more, at $\sim 18.1 \mathrm{cal} \mathrm{ka} \mathrm{BP}$, between $\sim 22.2$ and $\sim 15$ cal ka BP (Figure 5).

\section{Discussion}

\subsection{Scotia Sea Sea-Ice Reconstruction}

[15] The sediments in cores TPC286, TPC078 and TPC063 reveal changes in the sea-ice history across the Scotia Sea between $\sim 35$ and $\sim 15$ cal ka BP. From diatom sea-ice proxies we infer that both the SSI and WSI edges were intermittently present at $\sim 61^{\circ} \mathrm{S}$ (TPC286) between $\sim 35$ and $\sim 32$ cal ka BP, implying a narrow seasonal SIZ (Figures 5 and 6b). The North Scotia Sea (TPC063) remained ice free during this period as relative abundances of $F$. curta $+F$. cylindrus were $<3 \%$ (Figure 5 ). The first indication of the presence of the SSI edge at $\sim 55^{\circ} \mathrm{S}$ is evident $\sim 31$ cal ka BP (Figure 5) and is followed by a more sustained advance between $\sim 29$ and $\sim 23.5 \mathrm{cal} \mathrm{ka} \mathrm{BP}$, when total diatom concentrations were exceptionally low at site TPC286 (Figure 5), indicating limited biogenic production and perennial sea-ice cover. During this $\sim 6 \mathrm{kyr}$ period of perennial sea-ice, low total diatom concentrations and $>3 \%$ $F$. obliquecostata indicates that the SSI edge extended as far north as $\sim 55^{\circ} \mathrm{S}$ (TPC078) (Figures 5 and $6 \mathrm{~b}$ ), into the modern permanently open ocean zone (POOZ) (the area of annually open water north of the WSI edge and south of the APF zone (APFZ)) of the northern Central Scotia Sea. This confirms that more than half of the Scotia Sea was under permanent sea-ice cover, with a $\sim 12^{\circ}$ latitudinal expansion of the SSI edge prior to the global LGM $(\sim 21 \mathrm{ka})$. SSI did not reach as far north as $\sim 53^{\circ}$ (Figures 5 and 6). At approximately the same time the WSI edge advanced beyond $\sim 55^{\circ} \mathrm{S}$ and toward the northern margins of the basin, reaching at least $\sim 53^{\circ} \mathrm{S}$ (TPC063), close to the modern APFZ, by $\sim 25 \mathrm{cal} \mathrm{ka}$ BP when diatom sea-ice edge proxies first exceeded $3 \%$ at TPC063 (Figures 5 and 6). The WSI edge remained at $\sim 53^{\circ} \mathrm{S}$ until $\sim 23.5 \mathrm{cal} \mathrm{ka} \mathrm{BP}$, reaching a pre-LGM maximum at $\sim 24$ cal ka BP. WSI edge proxy fluctuations around the $3 \%$ threshold suggest that $\sim 53^{\circ} \mathrm{S}$ was close to the limit of maximum WSI extent in the North Scotia Sea, which represents a $\sim 3^{\circ}$ equatorward expansion compared with modern conditions, although there is evidence that further east the maximum WSI limit extended into the Falkland Trough [Allen et al., 2005, 2011] (Figure 2). Such a significant extension of the SSI edge, relative to the WSI edge, indicates that a relatively narrow seasonal SIZ was present between $\sim 29$ and $\sim 23.5$ cal ka BP with only $\sim 260 \mathrm{~km}$ between the average SSI and WSI limits (Figure 6b).

[16] The abrupt disappearance of the WSI edge from over site TPC063 at $\sim 23.5$ cal ka BP $(F$. curta $+F$. cylindrus $<3 \%$ ), accompanied by an increase in total diatom concentrations and a reappearance of the WSI edge at site TPC286 at $\sim 22.8$ cal ka BP (Figures 5 and $6 \mathrm{~b}$ ), suggests a strong meltback event involving the retreat of both the SSI and WSI fields across the Scotia Sea (by $\sim 6^{\circ}$ and $\sim 8^{\circ}$ latitude, respectively) (Figures 5 and $6 \mathrm{~b}$ ). Although this retreat is not evident at core site TPC078 (Figure 5), this could be due to the sampling resolution $(\sim 1.5 \mathrm{kyr})$ being greater than the duration of the event. Subsequent to this meltback event the SSI edge generally remained south of the Scotia Sea, with $F$. obliquecostata relative abundance indicating two brief re-advances over site TPC286 at $\sim 19.6$ and $\sim 17.8$ cal ka BP (Figures 5 and $6 \mathrm{~b}$ ). In contrast, the WSI edge re-advanced into the modern POOZ of the northern Central Scotia Sea (TPC078) from $\sim 22.5$ cal ka BP extending, intermittently as for north as $\sim 53^{\circ} \mathrm{S}$ (TPC063) (Figures 5 and $6 \mathrm{~b}$ ). The re-advance of the WSI edge subsequent to the meltback of both WSI and SSI edges marks a shift from a narrow seasonal SIZ to an extensive seasonal SIZ at $\sim 22.5$ cal ka BP (Figure $6 b$ ). The WSI edge finally retreated from the North Scotia Sea (TPC063) at $\sim 19.7 \mathrm{cal}$ ka BP, but remained in the northern Central Scotia Sea (TPC078) until $\sim 17.4$ cal ka BP before retreating from its advanced glacial position (Figures 5 and $6 \mathrm{~b}$ ).

[17] The combination of good chronological control and a relatively high sampling resolution during MIS 3 and MIS 2 has permitted the reconstruction of Scotia Sea sea-ice variability at a resolution higher than that achieved previously. We now compare our reconstruction (Figures 6 and 7a) with circum-Antarctic glacial sea-ice reconstructions of the EPILOG-LGM (E-LGM) 23-19 cal ka BP time slice [Gersonde et al., 2005] (Figure 6), the $\mathrm{ssNa}^{+}$-derived ice core sea-ice proxy (Figure 7i), and a range of well-dated paleoclimate records (Figure 7) and, finally, assess the extent to which 


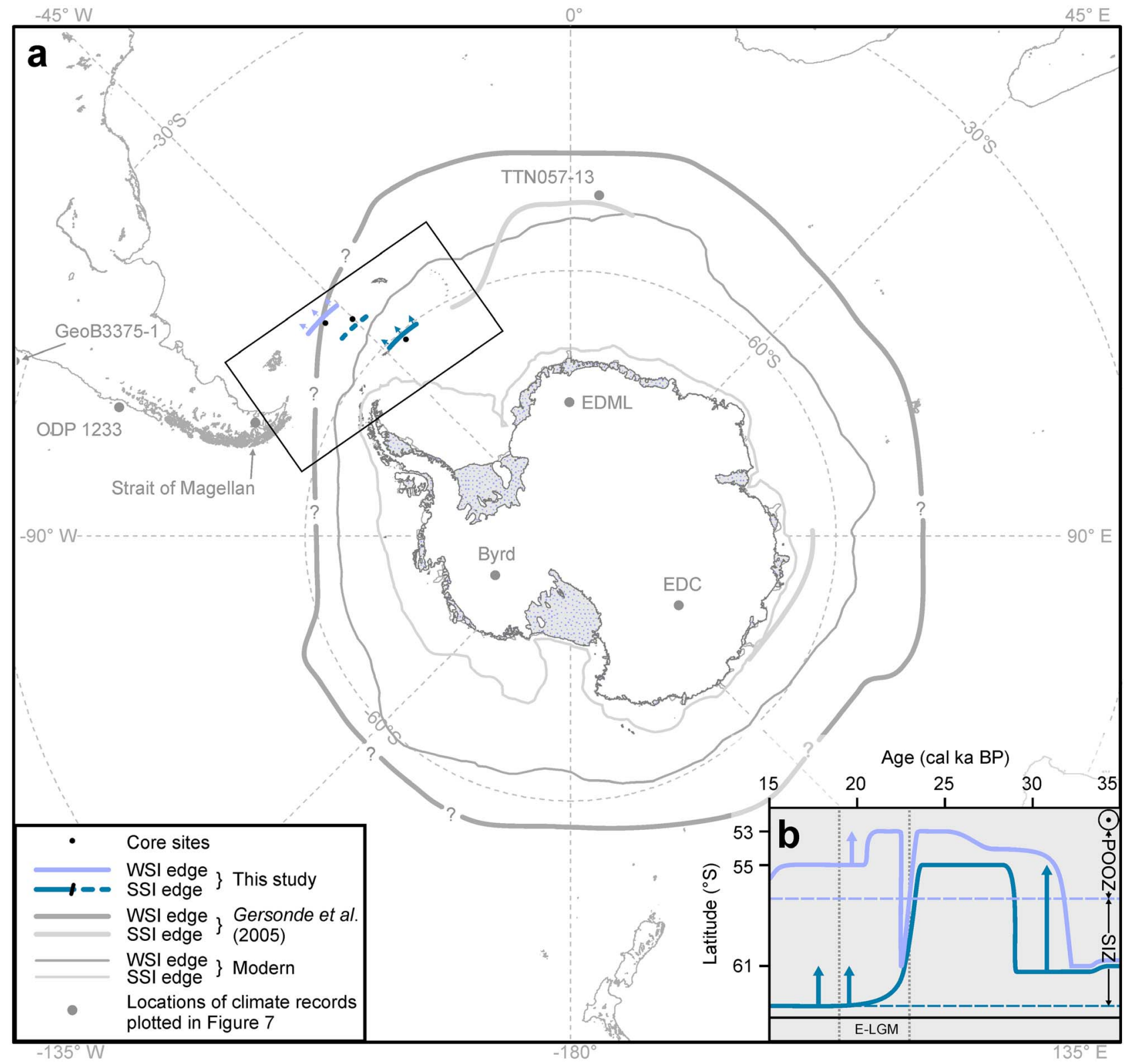

Figure 6. (a) Comparison of reconstructed maximum sea-ice edges presented here ( $24 \mathrm{cal} \mathrm{ka} \mathrm{B.P.)} \mathrm{(thick}$ colored lines) with the Gersonde et al. [2005] (thick gray lines) LGM reconstruction and modern limits (thin gray lines) (based on British Antarctic Survey [2007]). (b) Schematic representation of WSI (light purple line) and SSI (dark purple line) variability in the Scotia Sea between 35 and $15 \mathrm{cal} \mathrm{ka} \mathrm{BP,} \mathrm{with} \mathrm{relation} \mathrm{to} \mathrm{modern}$ sea-ice limits (horizontal dashed lines), modern locations of the seasonal sea-ice zone (SIZ), permanently open ocean zone (POOZ), the Antarctic Polar Front (dotted circle) and the EPILOG-LGM (E-LGM) timeslice (vertical dashed lines).

sea-ice-associated mechanisms may have been involved in the glacial lowering of atmospheric $\mathrm{CO}_{2}$ (Figures $7 \mathrm{~h}$ and 8).

\subsection{Winter Sea-Ice}

[18] Gersonde et al. [2005] propose that the WSI edge reached a maximum limit of $\sim 52^{\circ} \mathrm{S}$ in the Scotia Sea between $\sim 23$ and $\sim 19$ cal ka BP $(\sim 21$ cal ka B.P.) (Figure 6). Our results refine this estimate to between $\sim 25$ and $\sim 23.5 \mathrm{cal}$ ka BP (Figure 5) and, importantly, show that this maximum did not coincide with the LGM (taken as representing maximum terrestrial ice volume). Our preLGM maximum WSI limit is corroborated by a lower resolution sea-ice index from the South Atlantic [Stuut et al., 2004] and occurs at a similar time to maximum glacier advances in the Strait of Magellan, Patagonia, at 24.6 0.9 ka [Kaplan et al., 2008] (Figures 7b and 7c). Modeling and proxy studies suggest that an expansion of the SSI and WSI fields in the Scotia Sea could result in an intensification of the polar vortex and thus an equatorward shift of the circumpolar westerly wind belt. This would place cold, moisture- 


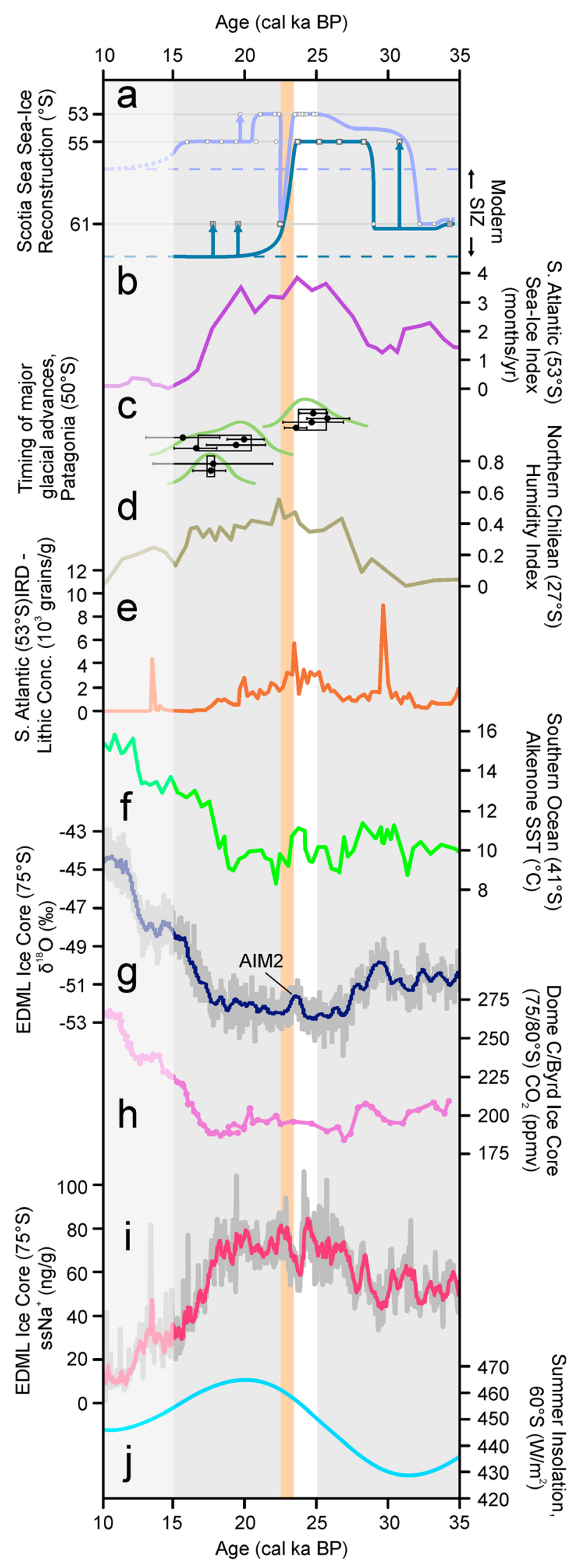

bearing air masses over Patagonia causing growth of mountain glaciers [Simmonds, 1981; Stuut, 2001; Lamy et al., 2001, 2002; Hulton et al., 2002]. The equatorward displacement of moisture-bearing air masses has also been linked with increasing strength of the midlatitude trade winds off the Southeast African coast and a decrease in the aridity of the Atacama desert, northern Chile [Stuut and Lamy, 2004] (Figure 7d). A peak in ice-rafted debris from the Southeast Atlantic [Kanfoush et al., 2000] also shows similarities with the timing of maximum WSI extent in the Scotia Sea (Figure 7e). Keany et al. [1976] suggested that variations in ice-rafted debris were also related to an equatorward displacement of the APFZ coinciding with the expansion of the SSI and WSI fields. The rapid retreat of the WSI edge after $\sim 23.5 \mathrm{cal} \mathrm{ka} \mathrm{BP}$, followed by a re-advance at $\sim 22.5 \mathrm{cal} \mathrm{ka}$ BP (Figure 7a), occurred $\sim 5 \mathrm{kyr}$ prior to the estimated onset of Southern Hemisphere deglaciation $(\sim 17.3 \pm 0.5$ cal ka BP $)$ [Schaefer et al., 2006]. The reconstructed sequence of events suggests the Scotia Sea experienced a brief period of warming, followed by a return to colder conditions, coincident (within age-model error) with the timing of Antarctic Isotope Maxima (AIM) 2 as shown in Antarctic ice cores [EPICA Community Members, 2006] and reflected in Southern Ocean SST records [Kaiser et al., 2005] (Figures $7 \mathrm{f}$ and $7 \mathrm{~g}$ ). Despite the apparent return of the WSI edge to the vicinity of core site TPC063 at $\sim 22.5$ cal ka BP, (Figure 7a) the diatom records

Figure 7. Comparison of reconstructed Antarctic sea-ice variability in the Scotia Sea with global records of millennial-scale climate change during the last glacial cycle. (a) Diatom-based sea-ice reconstruction, marine sediment cores TPC286 $\left(61^{\circ} \mathrm{S}\right)$, TPC078 $\left(55^{\circ} \mathrm{S}\right)$, TPC063 $\left(53^{\circ} \mathrm{S}\right)$, Scotia Sea, Atlantic sector of the Southern Ocean. Summer seaice (dark blue line), winter sea-ice (light blue line), modern sea-ice limits (dashed lines), arrows indicate short-term events, white circles indicate recorded winter sea-ice presence, dark gray squares indicate recorded summer sea-ice presence, white vertical band indicates sea-ice maxima, orange vertical band indicates sea-ice meltback event (this study). (b) Sea-ice presence index, marine sediment core TN057-13 from the Atlantic sector of the Southern Ocean, $53^{\circ} \mathrm{S}$ [Stuut and Lamy, 2004]. (c) Timing of major glacial advances in the Strait of Magellan, Patagonia, $50^{\circ} \mathrm{S}$ [Kaplan et al., 2008]. (d) Continental aridity time series from marine sediment core GeoB 3375-1 from the SE Pacific Ocean, offshore northern Chile, $27^{\circ} \mathrm{S}$ [Stuut and Lamy, 2004]. (e) Time series of total lithic concentration, size fraction $150 \mu \mathrm{m}-2 \mathrm{~mm}$, from marine sediment core TTN057-13, in the SE Atlantic, $53^{\circ} \mathrm{S}$ [Kanfoush et al., 2000]. (f) Alkenone sea surface temperature reconstruction at ODP Site 1233, SE Pacific Ocean, $41^{\circ} \mathrm{S}$ [Kaiser et al., 2005]. (g) Raw and smoothed $\delta^{18} \mathrm{O}$-derived temperature record from the high-resolution EPICA Dronning Maud Land ice core, Antarctica, $75^{\circ} \mathrm{S}$ [EPICA Community Members, 2004]. (h) Carbon dioxide records from EPICA Dome $\mathrm{C}$ and Byrd ice cores, Antarctica, $75^{\circ} \mathrm{S} / 80^{\circ} \mathrm{S}$ [Monnin et al., 2001; Ahn and Brook, 2008]. (i) Raw and smoothed ssNa ${ }^{+}$-derived sea-ice record from the high-resolution EPICA Dronning Maud Land ice core, Antarctica, $75^{\circ} \mathrm{S}$ [Fischer, 2008]. (j) Plot for austral summer (Dec/Jan/ $\mathrm{Feb}$ ) insolation at $60^{\circ} \mathrm{S}$ [Laskar et al., 2004]. 
presented here and by Allen et al. [2011] (TPC36) imply reduced SSI and WSI compared with that between $\sim 25$ and $\sim 23.5$ cal ka BP (Figure 5).

\subsection{Summer Sea-Ice}

[19] The expansion of SSI in the Scotia Sea as far north as $\sim 55^{\circ} \mathrm{S}$, initially at $\sim 31$ cal ka BP and gradually more extensively between $\sim 29$ and $\sim 23.5$ cal ka BP (Figure 6) validates the hypothesis of a pre-LGM SSI maximum [Allen et al., 2011]. In the eastern Atlantic Sector, Gersonde et al. [2003, 2005] also report an expansion of the SSI field to the modern WSI limit (edge of the seasonal SIZ) between 30 and $25 \mathrm{cal} \mathrm{ka} \mathrm{BP}$. Evidence of cooling during this interval is present in temperature records from the EDML ice core [EPICA Community Members, 2006] (Figure 7), and SST and sea-ice records from the Atlantic, Indian and Pacific Oceans [Charles et al., 1996; Gersonde et al., 2003; Armand and Leventer, 2003; Crosta et al., 2005a; Kaiser et al., 2005].

\subsection{The Seasonal Sea-Ice Zone}

[20] Our records support the Gersonde et al. [2005] interpretation of an enhanced seasonal SIZ during the E-LGM but

\section{a. Modern Southern Ocean: $\mathrm{CO}_{2}$ Out-gassing}

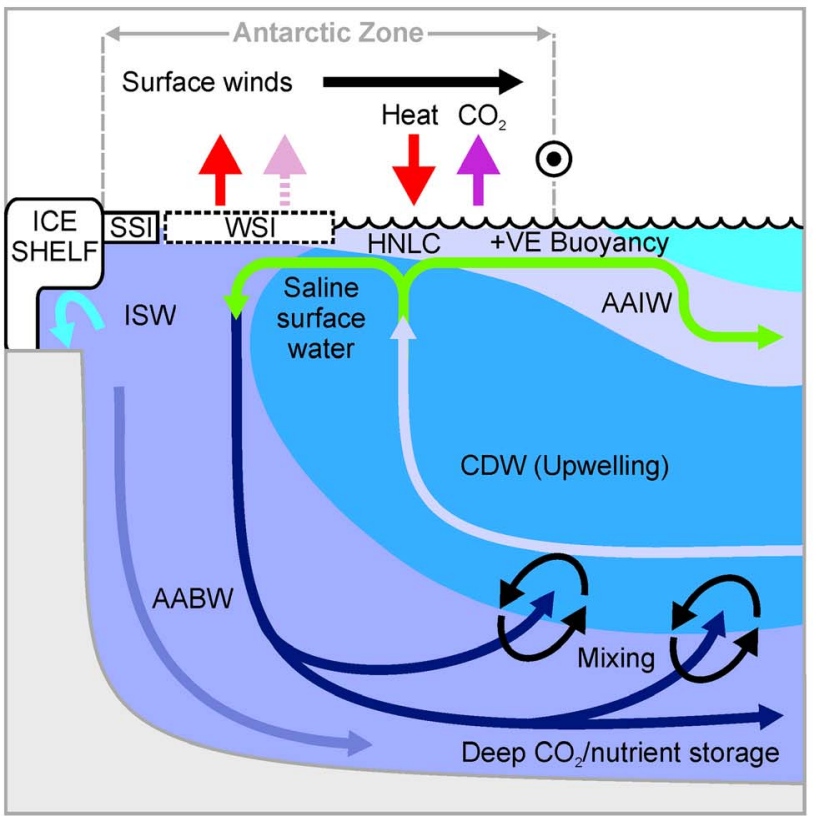

\section{c. AIM2: Warming Event}

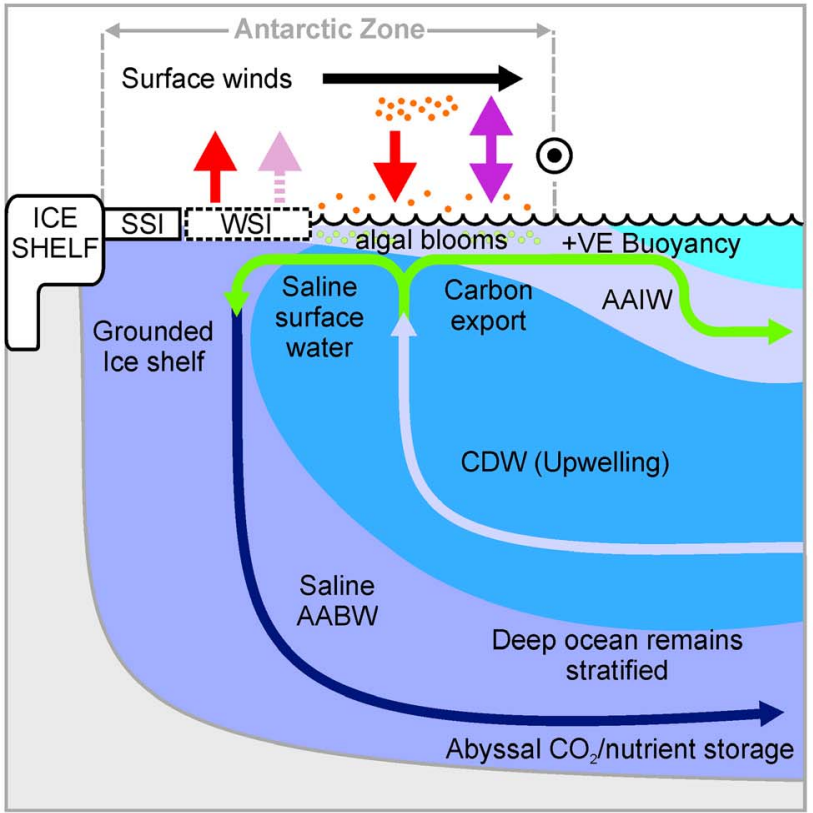

\section{b. Glacial: Narrow Seasonal SIZ}

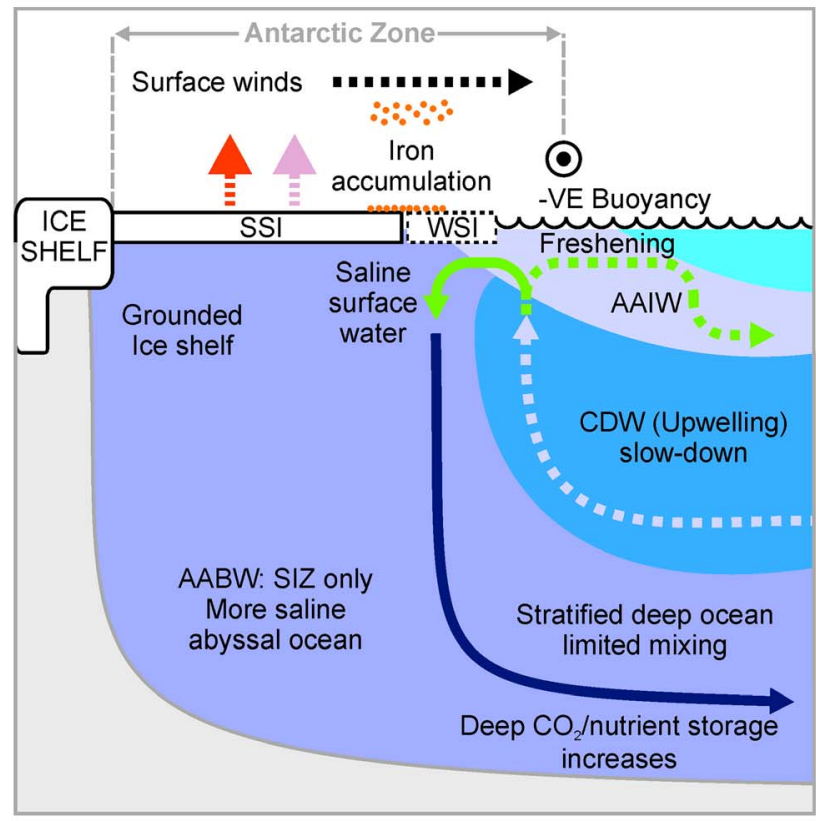

d. LGM: Expanded Seasonal SIZ

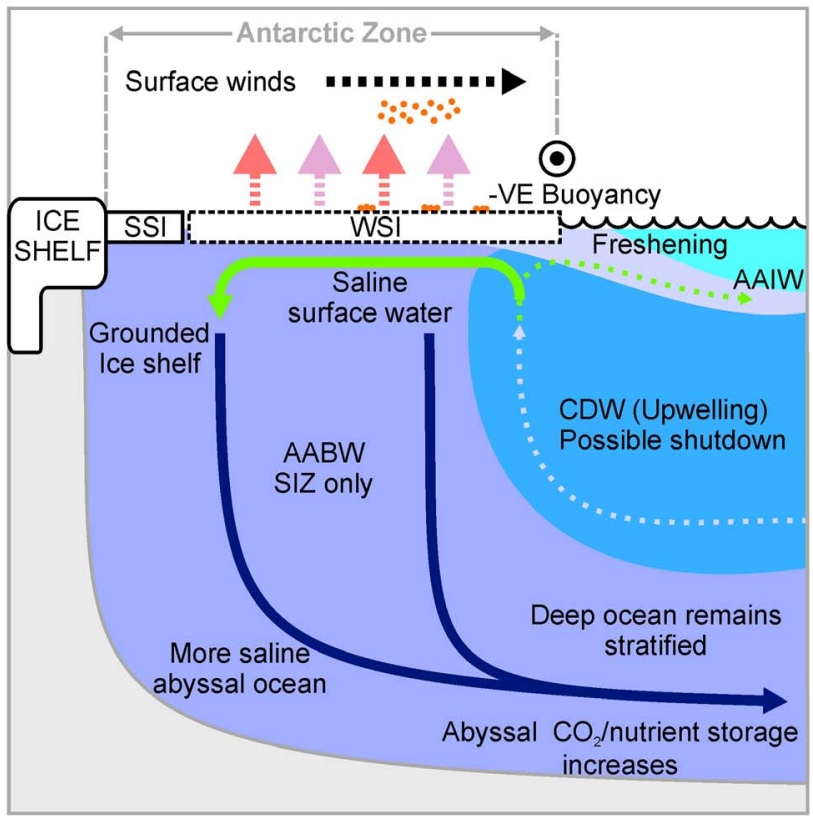

Figure 8 
we infer a reduced seasonal SIZ for a much longer period, between $\sim 35$ and $\sim 32$ cal $\mathrm{ka}$ BP and between $\sim 31$ and $\sim 23.5 \mathrm{cal}$ ka BP, building up to maximum sea-ice conditions between $\sim 25$ and $\sim 23.5$ cal ka BP (when both WSI and SSI edges were at their maximum extent) (Figure 7a). The sea-ice maximum was followed by a regime shift $(\sim 23.5-22.5 \mathrm{cal} \mathrm{ka}$ $\mathrm{BP}$ ) to a significantly enlarged seasonal SIZ (Figure 7a) that persisted from $\sim 22.5$ cal ka BP until deglaciation. This regime shift was broadly contemporaneous with maximum austral summer insolation $\left(60^{\circ} \mathrm{S}\right)$ (Figure $\left.7 \mathrm{j}\right)$.

\subsection{Marine Versus Ice Core Sea-Ice Proxies}

[21] Sea-salt sodium $\left(\mathrm{ssNa}^{+}\right)$concentration in ice cores has been used to reconstruct the past extent of Southern Ocean sea-ice over glacial-interglacial time-scales, with limited success [Wolff et al., 2003, 2006; Fischer et al., 2007; Röthlisberger et al., 2008, 2010]. Sea-salt ions incorporated into ice cores were originally thought to be derived from bubble bursting over the open ocean, beyond the sea-ice edge. However, based on the depletion of sulphate, Wolff et al. [2003] demonstrate that the majority of the $\mathrm{ssNa}^{+}$in ice cores in fact originates from the surface of newly forming sea-ice. Despite providing a more direct proxy of sea-ice than first thought there are a number of complications that must be considered. First, despite sea-salt production from blowing snow on sea-ice being found to be an order of magnitude higher than the sea-salt aerosol production from the open ocean [Röthlisberger et al., 2010], this open ocean source will still contribute to ice core sea-salt signal, particularly during ice-free summer months. Second, the sensitivity of the sea-salt proxy is severely limited during peak glacial conditions, when the sea-ice source is most distant from the sites of continental ice cores [Röthlisberger et al., 2008]. Comparisons with marine-based sea-ice reconstructions and modeling transport and depositions pathways can, in part, account for this deficiency but the proxy remains qualitative. Third, as the proxy is indicative of newly forming sea-ice, scenarios in the past when summer (multiyear) sea-ice was much more extensive and the seasonal SIZ was much reduced, the $\mathrm{ssNa}^{+}$sea-ice proxy is likely to provide a misrepresentation of overall sea-ice extent. At present, although promising, the sea-salt sodium-derived sea-ice proxy from ice cores remains a qualitative indicator of past seasonal (winter) sea-ice formation. Additional comparisons with down-core reconstructions of both WSI and SSI variability, particularly during peak glacial periods, are required to further develop this proxy.

[22] First order comparisons of our marine-derived sea-ice reconstruction and the sea-salt sodium $\left(\mathrm{ssNa}^{+}\right)$ice core record are reasonably consistent (within age-model errors) showing an increase to the glacial sea-ice maxima, the meltback and subsequent readvance of sea-ice during and following AIM 2 and the decrease in sea-ice extent across deglaciation. When the records are compared in more detail; the first significant advance of the WSI edge in our reconstruction is reflected by an increase in the $\mathrm{ssNa}^{+}$ice core record ( $~ 32$ cal ka BP) (Figure 7i). Reconstructed advances of the SSI edge at $\sim 31$ and $\sim 29$ cal ka BP (Figure 7a) coincide with decreases in $\mathrm{ssNa}^{+}$(Figure $7 \mathrm{i}$ ), consistent with a narrowing of the seasonal SIZ and thus a reduction in newly formed sea-ice. Our reconstructed WSI maximum is consistent with maximum $\mathrm{ssNa}^{+}$concentrations between 25.5 and 24 cal ka BP (within age-model errors) (Figures $7 \mathrm{a}$ and 7i). Furthermore, our reconstructed sea-ice meltback event is reflected by a sharp decrease in $\mathrm{ssNa}^{+}$concentrations between 24 and 23.6 cal ka BP, followed by a recovery to higher concentrations at $22.8 \mathrm{cal} \mathrm{ka} \mathrm{BP}$ (Figures $7 \mathrm{a}$ and 7i). Our reconstruction allows us to conclude that this decrease in $\mathrm{ssNa}^{+} \sim 24 \mathrm{cal} \mathrm{ka} \mathrm{BP}$ is not related to enhanced SSI extent (as appeared to be the case with decreases in $\mathrm{ssNa}^{+}$at $\sim 31$ and $\sim 29$ cal ka BP), but represents a genuine basin-wide retreat of sea-ice; a conclusion that would be difficult to draw from the $\mathrm{ssNa}^{+}$record alone. The short-term advance of the WSI edge to $\sim 53^{\circ} \mathrm{S}$, reconstructed at $\sim 19.7$ cal ka BP (Figure 7a), is potentially reflected by a spike in $\mathrm{ssNa}^{+}$concentrations at $19.3 \mathrm{cal} \mathrm{ka} \mathrm{BP}$ (within age model error) (Figure 7i). In our reconstruction the WSI edge stays at $\sim 55^{\circ} \mathrm{S}$ until $\sim 16$ cal ka BP (Figure $7 \mathrm{a}$ ), however, $\mathrm{ssNa}^{+}$ concentrations steadily decrease from $18 \mathrm{ka}$ (Figure 7i). Given that the EDML $\mathrm{ssNa}^{+}$record represents a regional signal, this difference between the diatom-derived and ssNa ${ }^{+}$-derived sea-ice records could be a response to the different timings of deglaciation around the Antarctic margin. Overall the EDML ssNa ${ }^{+}$sea-ice proxy agrees well with

\footnotetext{
Figure 8. Schematic diagram of the Southern Ocean today and in three glacial settings. (a) Modern Southern Ocean: $\mathrm{CO}_{2}$ Outgassing. (b) Glacial: Narrow Seasonal SIZ. (c) AIM2 Warming Event. (d) LGM: Expanded Seasonal SIZ. SSI, summer sea-ice; WSI, winter sea-ice (dashed box indicates seasonal presence); ISW, ice shelf water; HNLC, high nutrients low chlorophyll; AAIW, Antarctic intermediate water; CDW, circumpolar deep water; AABW, Antarctic bottom water (taken here to represent all Antarctic-formed deep water). Line thickness/style denotes strength of flow. Degree of 'blue' shading indicates extent of water masses associated with flows and circular (black) arrows represent up-mixing of $\mathrm{CO}_{2}$ - and nutrient-rich abyssal waters into overlying CDW. Vertical arrows denote direction of heat (red) and $\mathrm{CO}_{2}$ (purple) air-sea exchange, style of arrow denotes strength of the exchange. Position of the Antarctic Polar Front (APF) is indicated by a circled point and remains unchanged in all panels due to topographic constraints (not shown). In Figures 8b, 8c, and 8d Antarctic ice shelves are grounded across the continental shelf; thus AABW is more saline and the abyssal ocean denser, curtailing up-mixing into CDW. In Figures $8 \mathrm{~b}$ and $8 \mathrm{~d}$ upwelling strength and AAIW production is decreased relative to Figures $8 \mathrm{a}$ and $8 \mathrm{c}$ (thinner/dashed lines in Figures $8 \mathrm{~b}$ and 8d), suggested here to be the result of negative buoyancy at the APF induced by extended sea-ice cover (white boxes), which insulates and freshens surface waters, decreases the strength of northward flow (dashed light green lines) and thus suppresses $\mathrm{CO}_{2}$ out-gassing. During ice-free months in Figures 8b and 8d (not shown) and in Figure 8c, iron-fertilization (orange dots) induces strong algal blooms in the usually HNLC surface waters, leading to the export of organic carbon and further suppression of $\mathrm{CO}_{2}$ out-gassing (strong effect in Figure $8 \mathrm{c}$ due to accumulation of dust on extensive SSI (i.e., Figure 8b)). Despite stronger upwelling in Figure 8c, relative to Figures $8 \mathrm{~b}$ and $8 \mathrm{~d}$, iron-fertilization and reduced up-mixing limits and possibly prevents $\mathrm{CO}_{2}$ out-gassing.
} 
our diatom-based reconstruction of sea-ice variability in the Scotia Sea. The comparison demonstrates the strength of $\mathrm{ssNa}^{+}$record for determining long-term trends in WSI extent, including during the peak glacial when the proxy is considered less sensitive to sea-ice changes [Röthlisberger et al., 2010]. However, this comparison also identifies a tendency of $\mathrm{ssNa}^{+}$to underestimate total sea-ice extent during periods of expanded SSI during peak glacial periods. We therefore suggest that, in addition to increasing sea-ice extent and transport losses [Röthlisberger et al., 2010], estimates of SSI expansion must be taken into consideration when interpreting the ice core $\mathrm{ssNa}^{+}$signal.

\subsection{Southern Ocean Sea-Ice and the Carbon Cycle}

[23] The modern high-latitude Southern Ocean has been identified as an important location for the exchange of $\mathrm{CO}_{2}$ between the deep ocean and atmosphere [Sigman et al., 2010]. Nutrient-rich Antarctic surface waters are transported northward across the Antarctic Zone, forced by Ekman transport and, more importantly, surface water heat gain [Karsten and Marshall, 2002] (Figure 8a). The northward displacement of surface waters induces strong vertical mixing south of the APFZ and circumpolar deep water $(\mathrm{CDW})$, rich in pre-formed nutrients and dissolved inorganic carbon upwells into the Antarctic Zone (Figure 8a). In the Antarctic Zone the biological carbon pump is inefficient due to iron limitation, hence pre-formed nutrients are not utilized by phytoplankton at the surface and are subducted with Antarctic Intermediate Water (AAIW) leading to $\mathrm{CO}_{2}$ outgassing [Sigman et al., 2010] (Figure 8a). Warming of Antarctic Zone surface waters causes positive buoyancy at the APFZ, which results in stronger northward surface water transport and increased ventilation south of the APFZ; cooling of surface waters promotes the reverse [Olbers and Visbeck, 2005]. Increased surface buoyancy south of the APFZ leads to greater subduction of AAIW north of the APFZ [Olbers and Visbeck, 2005] (Figure 8a). For more than a decade, authors have proposed that these processes of deep water ventilation and the efficiency of the biological carbon pump are involved in the co-variation of atmospheric $\mathrm{CO}_{2}$ concentrations with temperatures observed in Antarctic ice cores [François et al., 1997; Stephens and Keeling, 2000; Toggweiler et al., 2006; Robinson and Sigman, 2008; Fischer et al., 2010; Hain et al., 2010].

[24] A number of mechanisms capable of suppressing deep water ventilation are proposed in the literature, including a reduction in surface water salinity [de Boer et al., 2008], uniquely dense deep waters [Adkins et al., 2002] and northward migration of the westerly wind belt [Toggweiler et al., 2006]. It has also been hypothesized that variations in Southern Ocean sea-ice can exert a dominant control on variations in atmospheric $\mathrm{CO}_{2}$ [Stephens and Keeling, 2000; Fischer et al., 2010]. Two mechanisms are proposed by which sea-ice can achieve this control: (1) a barrier mechanism (henceforth referred to as M1), whereby the insulating effect of an extensive permanent sea-ice (SSI) cap on air-sea gas exchange reduces $\mathrm{CO}_{2}$ out-gassing in the Antarctic Zone [Stephens and Keeling, 2000]; and (2) Antarctic stratification mechanism [François et al., 1997] (henceforth referred to as M2), whereby the expansion of WSI to the APFZ limits warming of Antarctic Zone surface waters, reduces/reverses positive surface buoyancy at the APFZ, decreases ventilation south of the APFZ, increases the efficiency of the biological pump and, thus, suppresses $\mathrm{CO}_{2}$ out-gassing in the Antarctic Zone [Watson and Garabato, 2006; Fischer et al., 2010].

[25] The barrier mechanism (M1) has been represented in a number of box-model experiments and is generally accepted to have a limited, yet potentially significant influence on atmospheric $\mathrm{CO}_{2}$ [Archer et al., 2003; Hain et al., 2010]. In contrast, the sea-ice Antarctic stratification mechanism (M2), proposed relatively recently, has not yet been tested in models, and due to its potential influence on vertical mixing and Antarctic nutrient cycling has a much greater potential to influence atmospheric $\mathrm{CO}_{2}[$ Archer et al., 2003; Hain et al., 2010].

[26] Knowledge of past sea-ice seasonal variability is essential to properly assess both the physical feasibility of these sea-ice mechanisms and their proposed control on atmospheric $\mathrm{CO}_{2}$. Until now M1 has only been compared with LGM time-slice sea-ice reconstructions that poorly map SSI, a critical component of the barrier hypothesis. M2 has been compared primarily with the ice core $\mathrm{ssNa}^{+}$-derived sea-ice proxy which, as discussed above, has limited sensitivity during peak glacial conditions and can misrepresent sea-ice extent during periods of extensive SSI. Our new sea-ice reconstruction, which reveals a complex evolution of the Scotia Sea seasonal SIZ between $\sim 35$ and $\sim 15$ cal ka BP (Figure 7a), allows us to consider whether sea-ice seasonal change is able to accommodate these proposed sea-ice mechanisms during the glacial. In addition, comparison with ice core $\mathrm{CO}_{2}$ records (Figure 7h) should allow us to determine the accuracy of the hypothesis that sea-ice exerted a major control on atmospheric $\mathrm{CO}_{2}$.

\subsubsection{Pre-LGM: Narrow Seasonal SIZ}

[27] Our sea-ice reconstruction (Section 4.1) is consistent with sea-ice acting as an extended insulating barrier (M1) [Stephens and Keeling, 2000] during the glacial, when SSI advanced to $\sim 61^{\circ} \mathrm{S}$ between $\sim 35$ and $\sim 32 \mathrm{cal} \mathrm{ka} \mathrm{BP}$, and to $\sim 55^{\circ} \mathrm{S}$ initially at $\sim 31$ cal ka BP and extensively between $\sim 29$ and $\sim 23.5$ cal ka. Regarding Antarctic stratification (M2), if the APFZ retained its modern position in the Scotia Sea due to topographical constraints [Moore et al., 2000; Olbers et al., 2004], the relative stability of the WSI edge, between $\sim 35$ and $\sim 32$ cal ka BP (Figure 7a), would have resulted in the persistence of an $\sim 11^{\circ}$ POOZ between the WSI edge and the APFZ. This would allow considerable heat uptake at the surface, which would limit the influence of M2. However, between $\sim 31$ and $\sim 25$ cal ka BP, WSI advance reduced the POOZ to $\sim 3^{\circ}$, limiting but not preventing the heat uptake and buoyancy gain of Antarctic Zone surface waters (Figure 8b), consistent with the operation of M2. Thus our reconstruction indicates that the potential influence of M2 steadily increased toward $\sim 25 \mathrm{cal}$ ka BP [Fischer et al., 2010].

[28] The ice core record of atmospheric $\mathrm{CO}_{2}$ declines to a low between $\sim 32$ and $\sim 31$ cal ka BP (Figure $7 \mathrm{~h}$ ), coeval (within age model constraints and record resolutions) with the expansion of winter and summer sea-ice from $\sim 61^{\circ}$ to $\sim 55^{\circ} \mathrm{S}$. This supports the influence of both M1 and M2 at this time, with the isolated advance of the SSI edge suppressing $\mathrm{CO}_{2}$ out-gassing and increasing WSI limiting CDW upwelling and promoting a more efficient biological pump. A more prominent decline in $\mathrm{CO}_{2}$ concentrations occurs at $\sim 29.7$ cal ka BP (Figure 7h), when the SSI edge advanced to 
its maximum glacial extent (north of $\sim 55^{\circ} \mathrm{S}$ ). At this time, our sea-ice reconstruction supports the influence of $\mathrm{M} 1$, with expanded SSI restricting air-sea gas exchange. Between $\sim 27$ and $\sim 25$ cal ka BP, $\mathrm{CO}_{2}$ concentrations gradually increase, during a period when both M1 and M2 should be approaching their maximum potential to influence atmospheric $\mathrm{CO}_{2}$ (expanded WSI and SSI). This brings into question the influence that either sea-ice mechanism has on $\mathrm{CO}_{2}$ reduction.

\subsubsection{Sea-Ice Maxima}

[29] If the APFZ was constrained by seafloor topography [Moore et al., 2000; Olbers et al., 2004], our sea-ice reconstruction (Section 4.1, Figure 7a) indicates that maximum potential influence of both sea-ice mechanisms (M1 and $\mathrm{M} 2$ ) on atmospheric $\mathrm{CO}_{2}$ concentrations should occur between $\sim 25$ and $\sim 23.5$ cal ka BP, when both SSI and WSI reached their maximum glacial extent and WSI extended to the APFZ. The WSI edge positioned at, or possibly beyond [Allen et al., 2011] the APFZ would have inhibited the warming of surface waters and induced negative buoyancy in the APFZ, considerably decreasing and probably shutting down deep water ventilation in the Antarctic Zone [Fischer et al., 2010]. As a result, $\mathrm{CO}_{2}$ out-gassing should have reached a minimum during this period. However, no decline is evident in the $\mathrm{CO}_{2}$ record (Figure 7h), again implying limited influence of $\mathrm{M} 1$ and $\mathrm{M} 2$ on atmospheric $\mathrm{CO}_{2}$.

[30] There is similarly no change in South Atlantic upwelling south of the APFZ at this time [Anderson et al., 2009], although $\delta^{13} \mathrm{C}$ measurements on benthic foraminifera tests from the South Atlantic do indicate a decline in AAIW formation during this period. This would be a direct consequence of negative buoyancy at the APFZ [Mortyn et al., 2003] and is supported by our sea-ice reconstruction. The reduction in atmospheric $\mathrm{CO}_{2}$ via sea-ice capping and sea-ice induced stratification could have been partly held in check by the reduced presence of polynyas. Polynyas are important $\mathrm{CO}_{2}$ sinks and existing evidence suggests that they were less extensive during maximum sea-ice extent [Mackensen, 2001; Krueger et al., 2012].

\subsubsection{AIM 2: Sea-Ice Meltback Event}

[31] Our sea-ice reconstruction indicates a period of transition between 23.5 and 22.5 cal ka BP, during which the meltback of the SSI edge occurred to at least $\sim 61^{\circ} \mathrm{S}$, shortly followed by the WSI edge (Figure 7a). This would have removed the insulating effects of sea-ice from the Scotia Sea. The subsequent reduced influence of both M1 and M2 on atmospheric $\mathrm{CO}_{2}$ concentrations would have permitted warming of surface waters, strong deep water ventilation and $\mathrm{CO}_{2}$ out-gassing (Figure $8 \mathrm{c}$ ). However, no increase is seen in the ice core record of atmospheric $\mathrm{CO}_{2}$ (Figure $7 \mathrm{~h}$ ). This is the strongest evidence to date that changes in Southern Ocean sea-ice exerted a limited influence on atmospheric $\mathrm{CO}_{2}$ concentrations during the glacial and that the dominance of other mechanisms, likely related to the efficiency of the biological pump, prevailed.

[32] The following explanation offers a potential reason for the lack of $\mathrm{CO}_{2}$ response during the interval $\sim 23.5-22.5 \mathrm{cal}$ $\mathrm{ka}$ BP that is coeval with AIM 2. A more extensive seasonal SIZ and more efficient biological carbon pump during this period could have promoted algal blooms and carbon export south of the APFZ [Robinson and Sigman, 2008], reducing $\mathrm{CO}_{2}$ out-gassing expected from the removal of the sea-ice cap (Figure 8c). Contrary to evidence compiled by Bopp et al. [2003], Abelmann et al. [2006] suggest that export production was enhanced in the glacial South Atlantic seasonal SIZ. Melting sea-ice released snow-settled dust into stratified surface waters fertilizing primary production and organic carbon export [Abelmann et al., 2006]. The bioavailability of iron from dust is enhanced by conditioning within snow accumulating on the sea-ice surface [Edwards and Sedwick, 2001], hence, the accumulation of snow/dust on an expanded, long-lived field of SSI would have a considerable effect on primary productivity in the seasonal SIZ upon its retreat, increasing the efficiency of the biological pump and reducing $\mathrm{CO}_{2}$ out-gassing (Figures $7 \mathrm{~b}$ and $7 \mathrm{c}$ ). Further, it is expected that a poleward sea-ice retreat would be accompanied by a poleward shift [Denton et al., 2010] and a strengthening of the westerly wind belt [Whittaker et al., 2011] and, thus, an increase in upwelling in the Antarctic Zone. Indeed, $\delta^{13} \mathrm{C}$ records from the mid-depth South Atlantic [Mortyn et al., 2003] do appear to show an increase in AAIW production north of the APFZ at this time, which would support the possibility of increased buoyancy at the APFZ [Olbers and Visbeck, 2005], although the amplitude of the increase in AAIW production may have been reduced by fresh surface waters related to WSI melt [Pahnke and Zahn, 2005]. However, upwelling proxies, in the form of biogenic opal burial rates, do not appear to suggest any increase in upwelling-induced productivity in the glacial South Atlantic during this period [Anderson et al., 2009]. A reduction in nutrient supply, despite enhanced upwelling and AAIW formation, could be a consequence of a more stratified deep ocean. Grounded ice on the Antarctic continental shelves during the glacial meant that most $\mathrm{AABW}$ was formed in the SIZ, generating a more saline deep water mass [Krueger et al., 2012] (Figure 8c), considerably more saline than today, and the modern salinity contrast between the South and North Atlantic was reversed [Adkins et al., 2002]. Stronger density gradients in the deep ocean promoted vertical stability, reducing the rate of diapycnal mixing between nutrient- and $\mathrm{CO}_{2}$-rich abyssal water and overlying $\mathrm{CDW}$ [Watson and Garabato, 2006] (Figures 7b, 7c, and 7d). Thus, even if upwelling of CDW in the Antarctic Zone was enhanced during this period due to a reduced sea-ice field and a more southerly position of the westerly winds, the upwelled water may have had a lower nutrient-content and lower $\mathrm{CO}_{2}$ concentration.

\subsubsection{Post-LGM: Expanded Seasonal SIZ}

[33] With the exception of two short-term re-advances at $\sim 19.6$ and $\sim 17.8$ cal ka BP, our sea-ice record shows the removal of SSI cover from the Scotia Sea from $\sim 22.5 \mathrm{cal}$ ka $\mathrm{BP}$, and thus the cessation of potential influence of the M1 seaice mechanism for influencing atmospheric $\mathrm{CO}_{2}$ concentrations (Figure 7a). However, the reconstructed re-advance of WSI to $\sim 53^{\circ} \mathrm{S}$ (retreating to $\sim 55^{\circ} \mathrm{S}$ at $\sim 19.7$ cal ka BP) (Figure 7a) would increase the influence of the M2 mechanism [Fischer et al., 2010], with a reduction in buoyancy reinforced by surface water freshening (Figure 8d) due to enhanced northward transport of sea-ice [Pahnke and Zahn, 2005; Watson and Garabato, 2006]. The suppressing influence of 
M2 on $\mathrm{CO}_{2}$ out-gassing would have gradually waned from $\sim 19.7$ cal ka BP as the WSI edge began to retreat from the vicinity of the APFZ and the seasonal SIZ narrowed. The atmospheric $\mathrm{CO}_{2}$ record changes little between $\sim 22.5$ and $\sim 20.6 \mathrm{cal}$ ka BP (Figure 7h), suggesting either limited influence of the $\mathrm{M} 1$ mechanism on $\mathrm{CO}_{2}$ out-gassing or that the $\mathrm{M} 2$ mechanism can compensate for the removal of year-round seaice cover. The retreat of WSI to $\sim 55^{\circ} \mathrm{S}$ (Figure 7a) coincides with a small peak in atmospheric $\mathrm{CO}_{2}$ at $\sim 20.5$ cal ka BP (Figure $7 \mathrm{~h}$ ) that could be related to a brief strengthening in vertical mixing (M2). A further reduction in atmospheric $\mathrm{CO}_{2}$ occurs between $\sim 20$ and $\sim 17.8$ cal ka BP (Figure $7 \mathrm{~h}$ ), possibly in response to short-term advances in SSI (Figure 7a) (weak M1), despite the gradual retreat of WSI poleward of the APFZ.

[34] The potential influence of M2 during this period is supported by a reduction in AAIW formation coinciding with the WSI edge re-advance (less buoyancy) at $\sim 22.5$ cal $\mathrm{ka} \mathrm{BP}$, and an increase in AAIW formation coeval with the onset of WSI edge retreat (more buoyancy) at $\sim 20$ cal ka BP [Mortyn et al., 2003]. The lack of a sustained increase in Antarctic Zone upwelling [Anderson et al., 2009] or atmospheric $\mathrm{CO}_{2}$ [EPICA Community Members, 2006] at $\sim 20 \mathrm{cal}$ ka BP could be explained by a combination of short-term advances in SSI (Figure 7a) and the continuation of dust fertilization supporting algal blooms and organic carbon export during ice-free months [Abelmann et al., 2006]. In addition, higher salinity AABW [Krueger et al., 2012] may have continued to reduce vertical water column mixing and lower the concentration of $\mathrm{CO}_{2}$ and pre-formed nutrients in upwelling CDW [Adkins et al., 2002]. A similar scenario is postulated by Sigman and Haug [2003], whereby thick nearcomplete sea-ice cover at the continental margin later drifts, melts and stratifies the open Antarctic, acting to prevent $\mathrm{CO}_{2}$ out-gassing during both summer and winter months.

\subsubsection{Deglaciation}

[35] Our reconstruction indicates that the glacial WSI edge began to retreat toward its modern position from $\sim 17.4$ cal ka BP (Figures 5 and 7a). This would have resulted in a broad POOZ capable of heat uptake and gradual suppression of the influence of the M2 mechanism on vertical mixing and, thus, $\mathrm{CO}_{2}$ out-gassing in the Antarctic Zone (Figure 8a). The Antarctic ice core atmospheric $\mathrm{CO}_{2}$ record shows increasing concentrations throughout this period (Figure 7h), potentially related to this gradual WSI retreat.

[36] The timing of WSI edge retreat coincides with the poleward migration of the westerly winds [Stuut and Lamy, 2004; Toggweiler et al., 2006], which would have intensified Southern Ocean overturning. The signature of positive surface buoyancy at this time is reflected by increased AAIW production [Mortyn et al., 2003; Pahnke and Zahn, 2005] and CDW upwelling [Anderson et al., 2009] in the South Atlantic. Atmospheric $\mathrm{CO}_{2}$ concentrations also increase [EPICA Community Members, 2006] because the reduced seasonal SIZ and creation of floating ice shelves across the continental shelf would have reduced the salinity of AABW [Krueger et al., 2012], reduced the density contrast in the deep Southern Ocean [Adkins et al., 2002] and enhanced vertical mixing and $\mathrm{CO}_{2}$ out-gassing. $\mathrm{CO}_{2}$ out-gassing also would have been enhanced by an inefficient biological carbon pump as iron once again became limiting [Martin, 1990] (Figure 8a), leading to a greater transfer of pre-formed nutrients into the ocean interior [Sigman et al., 2010].

\section{Conclusions}

[37] Based on improved chronological control, cores TPC286, TPC078 and TPC063 contain evidence that the Scotia Sea sea-ice field varied considerably during MIS 3 and MIS 2, in concert with major reorganizations of the climate system. The SSI edge expanded northward by up to $12^{\circ}$ latitude between $\sim 31$ and $\sim 23.5 \mathrm{cal} \mathrm{ka} \mathrm{BP}$, predating the LGM, and the WSI edge was displaced northward by at least $3^{\circ}$ latitude, with a maximum limit of $\sim 53^{\circ} \mathrm{S}$ between $\sim 25$ and $\sim 23.5$ cal ka BP. Both WSI and SSI edges experienced a rapid meltback event between $\sim 23.5$ and $\sim 22.8$ cal ka BP that coincided with Antarctic Isotopic Maximum 2. The Scotia Sea seasonal SIZ shifted from being narrow between $\sim 31$ and $\sim 23.5$ cal ka BP to much expanded between $\sim 22.5$ and $\sim 16$ cal ka BP. Our reconstructed evolution of the Scotia Sea sea-ice fields during MIS 3 to MIS 2 compares well with Antarctic temperature changes at the millennial-scale and generally compares favorably with the $\mathrm{ssNa}^{+}$sea-ice proxy, although it does highlight a clear $\mathrm{ssNa}^{+}$underestimate of seaice extent during periods of extensive SSI. Data presented here confirm that seasonal changes in Southern Ocean sea-ice, during the last glacial, had the potential to accommodate proposed sea-ice barrier [Stephens and Keeling, 2000] and seaice-induced stratification [Fischer et al., 2010] mechanisms and we strongly advocate the inclusion of the latter in future Southern Ocean carbon cycle modeling experiments. The clear lack of a $\mathrm{CO}_{2}$ response during maximum glacial sea-ice conditions and the basin-wide sea-ice retreat associated with Antarctic Isotopic Maximum 2 raises serious doubts as to whether Southern Ocean sea-ice exerted a controlling influence on the glacial lowering of atmospheric $\mathrm{CO}_{2}$. Similarities between our sea-ice reconstruction and the ice core $\mathrm{CO}_{2}$ record building up to and following glacial sea-ice maxima and the following meltback do suggest that sea-ice changes played an important role at these times. Additional high-resolution, welldated regional reconstructions of glacial Southern Ocean seaice variability, and their comparison with paleoclimate records of a comparable resolution, will further develop our understanding of sea-ice as an important component of millennialscale climate change and its potential influence on the global carbon cycle, deep ocean circulation and thus global climate.

[38] Acknowledgments. We thank the Captain, crew, and scientific parties aboard the RSS James Clark Ross during cruises JR04 and JR48 for their support during the collection of cores TPC063, TPC078, and TPC286. We also thank the NERC Radiocarbon Facility and M. Hounslow and V. Karloukovski of the Lancaster Environment Centre for their contribution to the chronology, Hilary Blagbrough for her contribution to diatom counts, K. Weckstrom for helpful and constructive comments on the manuscript, and $\mathrm{M}$. Hain and an anonymous reviewer for their thoughtful reviews of the manuscript. This research was supported by the British Antarctic Survey Quaternary Sediments work package led by D.A.H. and a Natural Environment Research Council (NERC) CASE studentship (NER/S/A 2005/13647) awarded to L.G.C.

\section{References}

Abelmann, A., R. Gersonde, G. Cortese, G. Kuhn, and V. Smetacek (2006) Extensive phytoplankton blooms in the Atlantic sector of the glacial Southern Ocean, Paleoceanography, 21, PA1013, doi:10.1029/ 2005PA001199.

Ackley, S. F. (1980), A review of sea-ice weather relationships in the Southern Hemisphere, in Proceedings of the Canberra Symposium: Sea 
Level, Ice, and Climatic Change, edited by A. Allision, IAHS Publ., 131, $127-159$.

Adkins, J. F., K. McIntyre, and D. P. Schrag (2002), The salinity, temperature, and $\delta^{18} \mathrm{O}$ of the glacial deep ocean, Science, 298, 1769-1773, doi:10.1126/ science. 1076252 .

Ahn, J., and E. J. Brook (2008), Atmospheric $\mathrm{CO}_{2}$ and climate on millennial time scales during the last glacial period, Science, 322, 83-85, doi:10.1126/science. 1160832

Allen, C. S., J. Pike, C. J. Pudsey, and A. Leventer (2005), Submillennial variations in ocean conditions during deglaciation based on diatom assemblages from the southwest Atlantic, Paleoceanography, 20, PA2012, doi:10.1029/2004PA001055.

Allen, C. S., J. Pike, and C. J. Pudsey (2011), Last glacial-interglacial sea-ice cover in the SW Atlantic and its potential role in global deglaciation, Quat. Sci. Rev., 30(19-20), 2446-2458, doi:10.1016/j.quascirev.2011.04.002.

Anderson, R. F., S. Ali, L. I. Bradtmiller, S. H. H. Nielsen, M. Q. Fleisher, B. E. Anderson, and L. H. Burckle (2009), Wind-driven upwelling in the Southern Ocean and the deglacial rise in atmospheric $\mathrm{CO}_{2}$, Science, 323, 1443-1448, doi:10.1126/science.1167441.

Archer, D. E., P. A. Martin, J. Milovich, V. Brovkin, G.-K. Plattner, and C. Ashendel (2003), Model sensitivity in the effect of Antarctic sea ice and stratification on atmospheric $\mathrm{pCO}_{2}$, Paleoceanography, 18(1), 1012, doi:10.1029/2002PA000760.

Armand, L. K., and A. Leventer (2003), Palaeo sea ice distribution, reconstruction and palaeoclimatic significance, in Sea Ice - An Introduction to its Physics, Chemistry, Biology and Geology, edited by D. N. Thomas and G. S. Dieckmann, pp. 333-372, Blackwell Sci., Oxford, U. K., doi:10.1002/9780470757161.ch11.

Armand, L. K., X. Crosta, O. Romero, and J.-J. Pichon (2005), The biogeography of major diatom taxa in Southern Ocean sediments: 1. Sea ice related species, Palaeogeogr. Palaeoclimatol. Palaeoecol., 223(1-2), 93-126, doi:10.1016/j.palaeo.2005.02.015.

Arrigo, K. A., M. P. Lizotte, D. L. Worthen, P. Dixon, and G. Dieckmann (1997), Primary production in Antarctic sea ice, Science, 276, 394-397, doi:10.1126/science. 276.5311 .394 .

Arzel, O., T. Fichefet, and H. Goosse (2006), Sea ice evolution over the 20th and 21 st centuries as simulated by current AO GCMs, Ocean Modell., 12 , 401-415, doi:10.1016/j.ocemod.2005.08.002.

Bentley, C. R. (1984), Some aspects of the cryosphere and its role in climatic change, in Climate Processes and Climate Sensitivity, Geophys. Monogr. Ser., vol. 29, edited by J. E. Hansen and T. Takahashi, pp. 207-220, AGU, Washington, D. C., doi:10.1029/GM029p0207.

Bopp, L., K. E. Kohfeld, and C. Le Quere (2003), Dust impact on marine biota and atmospheric $\mathrm{CO}_{2}$ during glacial periods, Paleoceanography, 18(2), 1046, doi:10.1029/2002PA000810.

Brandt, R. E., S. G. Warren, A. P. Worby, and T. C. Grenfell (2005), Surface albedo of the antarctic sea ice zone, J. Clim., 18(17), 3606-3622, doi:10.1175/JCLI3489.1.

British Antarctic Survey (2007), The Arctic and Antarctica, map, 1:10,000,000 scale, Cambridge, U. K.

Buffen, A., A. Leventer, A. Rubin, and T. Hutchins (2007), Diatom assemblages in surface sediments of the northwestern Weddell Sea, Antarctic Peninsula, Mar. Micropaleontol., 62(1), 7-30, doi:10.1016/j. marmicro.2006.07.002.

Burckle, L. H., and D. W. Cooke (1983), Late Pleistocene Eucampia antarctica abundance stratigraphy in the Atlantic sector of the Southern Ocean, Micropaleontology, 29(1), 6-10, doi:10.2307/1485648.

Charles, C. D., J. Lynch-Stieglitz, U. S. Ninnemann, and R. G. Fairbanks (1996), Climate connections between the hemispheres revealed by deep sea sediment core/ice core correlations, Earth Planet. Sci. Lett., 142, 19-27, doi:10.1016/0012-821X(96)00083-0.

Clement, A. C., and L. C. Peterson (2008), Mechanisms of abrupt climate change of the last glacial period, Rev. Geophys., 46, RG4002, doi:10.1029/ 2006RG000204.

CLIMAP Project Members (1976), The surface of the Ice-age Earth, Science, 191, 1131-1137, doi:10.1126/science.191.4232.1131.

CLIMAP Project Members (1981), Seasonal reconstruction of the Earth's surface at the last glacial maximum, http://www.ncdc.noaa.gov/paleo/ metadata/noaa-ocean-2516.html, World Data Cent of Paleoclimatology, Boulder, Colo.

Collins, L. G., M. Hounslow, C. S. Allen, D. A. Hodgson, J. Pike, and V. Karloukovski (2012), Palaeomagnetic and biostratigraphic dating of marine sediments from the Scotia Sea, Antarctica: First identification of the Laschamp excursion in the Southern Ocean, Quat. Geochronol., 7, 67-75, doi:10.1016/j.quageo.2011.10.002.

Cooke, D. W., and J. D. Hays (1982), Estimates of Antarctic ocean seasonal ice-cover during glacial intervals, in Antarctic Geoscience, edited by C. Craddock, pp. 1017-1025, Univ. of Wis. Press, Madison.
Crosta, X., J. J. Pichon, and L. H. Burckle (1998a), Application of modern analog technique to marine Antarctic diatoms: Reconstruction of maximum sea-ice extent at the Last Glacial Maximum, Paleoceanography, 13(3), 284-297, doi:10.1029/98PA00339.

Crosta, X., J. J. Pichon, and L. H. Burckle (1998b), Reappraisal of Antarctic seasonal sea-ice at the Last Glacial Maximum, Geophys. Res. Lett., 25(14), 2703-2706, doi:10.1029/98GL02012.

Crosta, X., A. Shemesh, J. Etourneau, R. Yam, I. Billy, and J. J. Pichon (2005a), Nutrient cycling in the Indian sector of the Southern Ocean over the last 50,000 years, Global Biogeochem. Cycles, 19, GB3007, doi:10.1029/2004GB002344.

Crosta, X., O. Romero, L. K. Armand, and J.-J. Pichon (2005b), The biogeography of major diatom taxa in Southern Ocean sediments: 2. Open ocean related species, Palaeogeogr. Palaeoclimatol. Palaeoecol., 223(1-2), 66-92, doi:10.1016/j.palaeo.2005.03.028.

Cunningham, W. L., and A. Leventer (1998), Diatom assemblages in surface sediments of the Ross Sea: Relationship to present oceanographic conditions, Antarct. Sci., 10(2), 134-146, doi:10.1017/S0954102098000182.

Cunningham, W. L., A. Leventer, J. T. Andrews, A. E. Jennings, and K. J. Licht (1999), Late Pleistocene-Holocene marine conditions in the Ross Sea, Antarctica: Evidence from the diatom record, Holocene, 9(2), 129-139, doi:10.1191/095968399675624796.

de Boer, A. M., J. R. Toggweiler, and D. M. Sigman (2008), Atlantic dominance of the meridional overturning circulation, J. Phys. Oceanogr., 38 , 435-450.

Denton, G. H., R. F. Anderson, J. R. Toggweiler, R. L. Edwards, J. M Schaefer, and A. E. Putnam (2010), The last glacial termination, Science, 328, 1652-1656, doi:10.1126/science.1184119.

Diekmann, B., G. Kuhn, V. Rachold, A. Abelmann, U. Brathauer, D. K. Fütterer, R. Gersonde, and H. Grobe (2000), Terrigenous sediment supply in the Scotia Sea (Southern Ocean): Response to Late Quaternary ice dynamics in Patagonia and on the Antarctic Peninsula, Palaeogeogr. Palaeoclimatol. Palaeoecol., 162, 357-387, doi:10.1016/S0031-0182 (00)00138-3.

Diekmann, B. D. Futterer, H. Grobe, C. D. Hillenbrand, G. Kuhn, K. Michels, R. Petschick, and M. Pirrung (2003), Terrigenous sediment supply in the polar to temperate South Atlantic: Landeocean links of environmental changes during the late quaternary, in The South Atlantic in the Late Quaternary: Reconstruction of Material Budgets and Current Systems, edited by B. Diekmann et al., pp. 375-399, Springer, Berlin.

Edwards, R., and P. N. Sedwick (2001), Iron in East Antarctic snow: Implications for atmospheric iron deposition and algal production in Antarctic waters, Geophys. Res. Lett., 28, 3907-3910, doi:10.1029/2001GL012867.

EPICA Community Members (2004), Eight glacial cycles from an Antarctic ice core, Nature, 429, 623-628, doi:10.1038/nature02599.

EPICA Community Members (2006), One-to-one coupling of glacial climate variability in Greenland and Antarctica, Nature, 444, 195-198, doi:10.1038/nature 05301

Fischer, H. (2008), EPICA EDML chemical concentrations and fluxes, http:// doi.pangaea.de/10.1594/PANGAEA.683642, PANGAEA, Network for Geol. and Environ. Data, Germany.

Fischer, H., et al. (2007), Reconstruction of millennial changes in dust emission, transport and regional sea ice coverage using the deep EPICA ice cores from the Atlantic and Indian Ocean sector of Antarctica, Earth Planet. Sci. Lett., 260, 340-354, doi:10.1016/j.eps1.2007.06.014.

Fischer, H., et al. (2010), The role of Southern Ocean processes in orbial and millennial $\mathrm{CO}_{2}$ variations - A synthesis, Quat. Sci. Rev., 29, 193-205, doi:10.1016/j.quascirev.2009.06.007

Foldvik, A., and T. Gamelsrod (1988), Notes on Southern Ocean hydrography, sea-ice and bottom water formation, Palaeogeogr. Palaeoclimatol. Palaeoecol., 67, 3-17, doi:10.1016/0031-0182(88)90119-8.

Fortin, M.-J., and M. R. T. Dale (2008), Spatial Analysis: A Guide for Ecologists, Cambridge Univ. Press, Cambridge, U. K.

François, R., M. A. Altabet, E.-F. Yu, D. M. Sigman, M. P. Bacon, M. Frankk, G. Bohrmann, G. Bareille, and L. D. Labeyrie (1997), Contribution of Southern Ocean surface-water stratification to low atmospheric $\mathrm{CO}_{2}$ concentrations during the last glacial period, Nature, 389, 929-935, doi: $10.1038 / 40073$.

Fryxell, G., and G. R. Hasle (1979), The genus Thalassiosira: Species with internal extensions of the strutted processes, Phycologia, 18, 378-393, doi:10.2216/i0031-8884-18-4-378.1.

Fryxell, G. A., and A. K. S. K. Prasad (1990), Eucampia antarctic var. recta (Mangin) stat. nov. (Biddulphiaceae, Bacillariophyceae): Life stages at the Weddell Sea ice edge, Phycologia, 29(1), 27-38, doi:10.2216/ i0031-8884-29-1-27.1.

Gersonde, R., and U. Zielinski (2000), The reconstruction of late Quaternary Antarctic sea-ice distribution - the use of diatoms as a proxy for sea-ice, Palaeogeogr. Palaeoclimatol. Palaeoecol., 162, 263-286, doi:10.1016/S0031-0182(00)00131-0. 
Gersonde, R., et al. (2003), Last glacial sea surface temperatures and sea-ice extent in the Southern Ocean (Atlantic-Indian sector): A multiproxy approach, Paleoceanography, 18(3), 1061, doi:10.1029/2002PA000809.

Gersonde, R., X. Crosta, A. Abelmann, and L. Armand (2005), Sea-surface temperature and sea ice distribution of the Southern Ocean at the EPILOG Last Glacial Maximum-A circum-Antarctic view based on siliceous microfossil records, Quat. Sci. Rev., 24(7-9), 869-896, doi:10.1016/j. quascirev.2004.07.015.

Gildor, H., and E. Tziperman (2001), A Sea-ice climate-switch mechanism for the $100 \mathrm{kyr}$ glacial cycles, J. Geophys. Res., 106(C5), 9117-9133, doi:10.1029/1999JC000120.

Gordon, A. L. (1991), The Southern Ocean. Its involvement in global change, in Proceedings of the International Conference on the Role of the Polar Regions in Global Change, edited by G. Weller et al., pp. 249-255, Univ. of Alaska Fairbanks, Fairbanks.

Guillou, H., B. S. Singer, C. Laj, C. Kissel, S. Scaillet, and B. R. Jicha (2004), On the age of the Laschamp geomagnetic excursion, Earth Planet. Sci. Lett., 227, 331-343, doi:10.1016/j.eps1.2004.09.018.

Hain, M. P., D. M. Sigman, and G. H. Haug (2010), Carbon dioxide effects of Antarctic stratification, North Atlantic Intermediate Water formation, and subantarctic nutrient drawdown during the last ice age: Diagnosis and synthesis in a geochemical box model, Global Biogeochem. Cycles, 24, GB4023, doi:10.1029/2010GB003790.

Hays, J. D., J. A. Lozano, N. J. Shackleton, and G. Irving (1976), Reconstruction of the Atlantic and western Indian Ocean sectors of the 18,000 BP Antarctic Ocean, in Investigation of Late Quaternary Paleoceanography and Paleoclimatology, edited by R. M. Cline and J. D. Hays, Geol. Soc. Am. Mem., 145, 337-372.

Hofmann, D. I., K. Fabian, F. Schmieder, B. Donner, and U. Bleil (2005), A stratigraphic network across the Subtropical Front in the central South Atlantic: Multi-parameter correlation of magnetic susceptibility, density, X-ray fluoresence and $\delta^{18} \mathrm{O}$ records, Earth Planet. Sci. Lett., 240, 694-709, doi:10.1016/j.eps1.2005.09.048.

Holm-Hansen, O., and B. G. Mitchell (1991), Spatial and temporal distribution of phytoplankton and primary production in the western Bransfield Strait region, Deep Sea Res., Part A, 38, 961-980, doi:10.1016/01980149(91)90092-T.

Hulton, N. R. J., T. S. Purves, R. D. McCulloch, D. E. Sugden, and M. J. Bentley (2002), The Last Glacial maximum and deglaciation in southern South America, Quat. Sci. Rev., 21, 233-241, doi:10.1016/S0277-3791 (01)00103-2.

Kaiser, J., F. Lamy, and D. Hebbeln (2005), A 70-kyr sea surface temperature record off southern Chile (Ocean Drilling Programme Site 1233), Paleoceanography, 20, PA4009, doi:10.1029/2005PA001146.

Kanfoush, S. L., D. A. Hodell, C. D. Charles, T. P. Guilderson, P. G. Mortyn, and U. S. Ninnemann (2000), Millennial-scale instability of the Antarctic Ice Sheet during the last glaciation, Science, 288, 1815-1819, doi:10.1126/science.288.5472.1815.

Kaplan, M. R., C. J. Fogwill, D. E. Sugden, N. R. J. Hulton, P. W. Kubik, and S. P. H. T. Freeman (2008), Southern Patagonian glacial chronology for the Last Glacial period and implications for Southern Ocean climate, Quat. Sci. Rev., 27(3-4), 284-294, doi:10.1016/j.quascirev.2007.09.013.

Karsten, R. H., and J. Marshall (2002), Constructing the residual circulation of the ACC from observations, J. Phys. Oceanogr., 32, 3315-3327, doi:10.1175/1520-0485(2002)032<3315:CTRCOT $>2.0 . C O ; 2$

Keany, J., M. Ledbetter, N. Watkins, and T.-C. Huang (1976), Diachronous deposition of ice-rafted debris in sub-Antarctic deep-sea sediments, Geol. Soc. Am. Bull., 87, 873-882, doi:10.1130/0016-7606(1976)87<873: DDOIDI $>2.0 . \mathrm{CO} ; 2$.

Knorr, G., and G. Lohmann (2003), Southern Ocean origin for the resumption of Atlantic thermohaline circulation during deglaciation, Nature, 424, 532-536, doi:10.1038/nature01855.

Krueger, S., D. C. Leuschner, W. Ehrmann, G. Schmiedl, and A. Mackensen (2012), North Atlantic Deep Water and Antarctic Bottom Water variability during the last $200 \mathrm{ka}$ record in an abyssal sediment core off South Africa, Global Planet. Change, 80-81, 180-189, doi:10.1016/j. gloplacha.2011.10.001.

Lamy, F., D. Hebbeln, U. Pfhl, and G. Wefer (2001), Holocene rainfall variability in southern Chile: A marine record of latitudinal shifts of the Southern Westerlies, Earth Planet. Sci. Lett., 185, 369-382, doi:10.1016/S0012-821X(00)00381-2.

Lamy, F., C. Ruhlemann, D. Hebbeln, and G. Wefer (2002), High- and lowlatitude climate control on the position of the southern Peru-Chile current during the Holocene, Paleoceanography, 17(2), 1028, doi:10.1029/ 2001 PA000727.

Laskar, J., P. Robutel, F. Joutel, M. Gastineau, A. C. M. Correia, and B. Levrard (2004), A long-term numerical solution for the insolation quantities of the Earth, Astron. Astrophys., 428(1), 261-285, doi:10.1051/ 0004-6361:20041335.
Leventer, A., and R. B. Dunbar (1996), Factors influencing the distribution of diatoms and other algae in the Ross Sea, J. Geophys. Res., 101(C8), 18,489-18,500, doi:10.1029/96JC00204

Leventer, A., E. W. Domack, S. E. Ishman, S. Brachfeld, C. E. McClennen and P. Manley (1996), Productivity cycles of 200-300 years in the Antarctic Peninsula region: Understanding linkages among the sun, atmosphere, oceans, sea ice, and biota, Geol. Soc. Am. Bull., 108(12), 1626-1644, doi:10.1130/0016-7606(1996)108<1626:PCOYIT $>2.3 . C O ; 2$

Liu, Z. Y., S. I. Shin, R. S. Webb, W. Lewis, and B. L. Otto-Bliesner (2005), Atmospheric CO2 forcing on glacial thermohaline circulation and climate, Geophys. Res. Lett., 32, L02706, doi:10.1029/ 2004GL021929.

Mackensen, A. (2001), Oxygen and carbon stable isotope tracers of Weddell Sea water masses: New data and some paleoceanographic implications, Deep Sea Res., Part I, 48(6), 1401-1422, doi:10.1016/ S0967-0637(00)00093-5.

Martin, J. (1990), Glacial-interglacial $\mathrm{CO}_{2}$ change: The iron hypothesis, Paleoceanography, 5, 1-13, doi:10.1029/PA005i001p00001.

Monnin, E., A. Indermuhle, A. Dallenbach, J. Fluckiger, B. Stauffer, T. Stocker, D. Raynaud, and J.-M. Barnola (2001), Atmospheric $\mathrm{CO}_{2}$ concentrations over the last glacial termination, Science, 291, 112-114, doi:10.1126/science.291.5501.112.

Moore, J. K., M. R. Abbott, J. G. Richman, and D. M. Nelson (2000), The Southern Ocean at the last glacial maximum: A strong sink for atmospheric carbon dioxide, Global Biogeochem. Cycles, 14, 455-475, doi:10.1029/1999GB900051.

Mortyn, P. G., C. D. Charles, U. S. Ninnemann, K. Ludwig, and D. A. Hodell (2003), Deep sea sedimentary analogs for the Vostok ice core Geochem. Geophys. Geosyst., 4(8), 8405, doi:10.1029/2002GC000475.

Olbers, D., and M. Visbeck (2005), A model of the zonally averaged stratification and overturning in the Southern Oean, J. Phys. Oceanogr., 35, 1190-1205, doi:10.1175/JPO2750.1.

Olbers, D., D. Borowski, C. Völker, and J. O. Wolff (2004), The dynamical balance, transport and circulation of the Antarctic Circumpolar Current, Antarct. Sci., 16, 439-470, doi:10.1017/S0954102004002251.

Pahnke, K., and R. Zahn (2005), Southern hemisphere water mass conversion linked with North Atlantic climate variability, Science, 307, 1741-1746, doi:10.1126/science.1102163.

Paillard, D., L. Labeyrie, and P. Yiou (1996), Macintosh program performs time-series analysis, Eos Trans. $A G U, 77,379$, doi:10.1029/ 96EO00259.

Parrenin, F., et al. (2007), The EDC3 chronology for the EPICA Dome C ice core, Clim. Past, 3, 485-497, doi:10.5194/cp-3-485-2007.

Pudsey, C. J., and J. A. Howe (1998), Quaternary history of the Antarctic Circumpolar Current: Evidence from the Scotia Sea, Mar. Geol., 148(1-2), 83-112, doi:10.1016/S0025-3227(98)00014-0.

Pugh, R. S., I. N. McCave, C. D. Hillenbrand, and G. Kuhn (2009), CircumAntarctic age modelling of Quaternary marine cores under the Antarctic Circumpolar Current: Ice-core dust.magnetic correlation, Earth Planet. Sci. Lett., 284, 113-123, doi:10.1016/j.epsl.2009.04.016.

Randall, D. A., et al. (2007), Climate models and their evaluation, in Climate Change 2007: The Physical Science Basis. Contribution of Working Group I to the Fourth Assessment Report of the Intergovernmental Panel on Climate Change, edited by D. A. Randall et al., pp. 589-662, Cambridge Univ. Press, Cambridge, U. K.

Robinson, R. S., and D. M. Sigman (2008), Nitrogen isotopic evidence for a poleward decrease in surface nitrate, Quat. Sci. Rev., 27, 1076-1090, doi:10.1016/j.quascirev.2008.02.005.

Röthlisberger, R., et al. (2008), The Southern Hemisphere at glacial terminations: Insights from the Dome C ice core, Clim. Past, 4, 345-356, doi:10.5194/cp-4-345-2008

Röthlisberger, R., X. Crosta, N. J. Abrama, L. Armand, and E. W. Wolff (2010), Potential and imitations of marine and ice core sea ice proxies: An example from the Indian Ocean sector, Quat. Sci. Rev., 29, 296302, doi:10.1016/j.quascirev.2009.10.005.

Schaefer, J. M. G. H. Denton, D. J. A. Barrell, S. Ivy-Ochs, P. W. Kubik, B. G. Andersen, F. M. Phillips, T. V. Lowell, and C. Schluchter (2006), Near-synchronous interhemispheric termination of the last glacial maximum in mid-latitudes, Science, 312, 1510-1513, doi:10.1126/science.1122872.

Scherer, R. P. (1994), A new method for the determination of absolute abundance of diatoms and other silt-sized sedimentary particles, J. Paleolimnol. 12, 171-179, doi:10.1007/BF00678093.

Shemesh, A., D. A. Hodell, X. Crosta, S. L. Kanfoush, C. D. Charles, and T. P. Guilderson (2002), Sequence of events during the last deglaciation in Southern Ocean sediments and Antarctic ice cores, Paleoceanography, 17(4), 1056, doi:10.1029/2000PA000599.

Shin, S. I., Z. G. Liu, B. L. Otto-Bliesner, J. E. Kutzbach, and S. J. Vavrus (2003), Southern Ocean sea-ice control of the glacial North Atlantic 
thermohaline circulation, Geophys. Res. Lett., 30(2), 1096, doi:10.1029/ 2002GL015513.

Sigman, D. M., and G. H. Haug (2003), The biological pump in the past, in The Oceans and Marine Geochemistry, Treatise Geochem., vol. 6, edited by H. D. Holland and K. K. Turekian, pp. 491-528, Elseiver, Amsterdam, doi:10.1016/B0-08-043751-6/06118-1.

Sigman, D. M., M. P. Hain, and G. H. Haug (2010), The polar ocean and glacial cycles in atmospheric $\mathrm{CO}_{2}$ concentration, Nature, 466, 47-55, doi:10.1038/nature09149.

Simmonds, I. (1981), The effect of sea ice on a general circulation model of the Southern Hemisphere, IAHS Publ., 131, 193-206.

Stephens, B. B., and R. F. Keeling (2000), The influence of Antarctic sea ice on glacial-interglacial $\mathrm{CO}_{2}$ variations, Nature, 404, 171-174, doi: $10.1038 / 35004556$.

Stoner, J. S., C. Laj, J. E. T. Channell, and C. Kissel (2002), South Atlantic and North Atlantic geomagnetic paleointensity stacks (0-80 ka): Implications for inter-hemispheric correlation, Quat. Sci. Rev., 21(10), 1141-1151, doi:10.1016/S0277-3791(01)00136-6.

Stuut, J.-B. W. (2001), Late Quaternary southwestern African terrestrial climate signals in the marine record of Walvis Ridge, SE Atlantic Ocean, PhD thesis, Utrecht Univ., Utrecht, Netherlands.

Stuut, J.-B. W., and F. Lamy (2004), Climate variability at the southern boundaries of the Namib (southwestern Africa) and Atacama (northern Chile) coastal deserts during the last 120,000 yrs, Quat. Res., 62, 301-309, doi:10.1016/j.yqres.2004.08.001.

Stuut, J.-B. W., X. Crosta, K. van der Borg, and R. Schneider (2004), Relationship between Antarctic sea ice and southwest African climate during the Late Quaternary, Geology, 32(10), 909-912, doi:10.1130/G20709.1.

Takahashi, T., et al. (2009), Climatological mean and decadal change in surface ocean $\mathrm{pCO}_{2}$, and net sea-air $\mathrm{CO}_{2}$ flux over the global oceans, Deep Sea Res., Part II, 56, 554-577, doi:10.1016/j.dsr2.2008.12.009.
Taylor, F., and A. Leventer (2003), Late quaternary palaeoenvironments in Prydz Bay, East Antarctica: Interpretations from marine diatoms, Antarct. Sci., 15(4), 512-521, doi:10.1017/S0954102003001639.

Taylor, F. J. Whitehead, and E. Domack (2001), Holocene paleoclimate change in the Antarctic Peninsula: evidence from the diatom, sedimentary and geochemical record, Mar. Micropaleontol., 41, 25-43, doi:10.1016/ S0377-8398(00)00049-9.

Toggweiler, J. R., J. L. Russell, and S. R. Carson (2006), Midlatitude westerlies, atmospheric $\mathrm{CO} 2$ and climate change during the ice ages, Paleoceanography, 21, PA2005, doi:10.1029/2005PA001154.

Tomas, C. R. (1997), Identifying Marine Phytoplankton, Academic, New York.

Watson, A. J., and A. C. N. Garabato (2006), The role of Southern Ocean mixing and upwelling in glacial-interglacial atmospheric $\mathrm{CO}_{2}$ change, Tellus, Ser. B, 58, 73-87.

Whittaker, T. E., C. H. Hendy, and J. C. Hellstrom (2011), Abrupt millennialscale changes in intensity of Southern Hemisphere westerly winds during marine isotope stages 2-4, Geology, 39(5), 455-458, doi:10.1130/ G31827.1.

Wolff, E. W., A. M. Rankin, and R. Rothlisberger (2003), An ice core indicator of Antarctic sea ice production? Geophys. Res. Lett., 30(22), 2158 , doi:10.1029/2003GL018454.

Wolff, E. W., et al. (2006), Southern Ocean sea ice, DMS production and iron flux over the last eight glacial cycles, Nature, 440, 491-496, doi: 10.1038 /nature 04614

Wu, X., I. Simmonds, and W. F. Budd (1997), Modeling of Antarctic Sea-ice in a General Circulation Model, J. Clim., 10, 593-609, doi:10.1175/1520 0442(1997)010<0593:MOASII>2.0.CO;2. 